\title{
Patent Demands \& Startup Companies: The VieW From the Venture Capital Community
}

\author{
Robin Feldman ${ }^{*}$
}

\author{
16 YALE J.L. \& TECH. 236 (2014)
}

\begin{abstract}
With the high level of interest in patent monetization and its effects on US companies, data on the topic is increasingly important. This study examines one aspect of the topic, focusing on the effects of the rising patent monetization market on startup companies. The study provides one of the rare glimpses of monetization activity outside of lawsuits. It provides both quantitative and qualitative information on the startup community's experience with and perspectives on patent demands. Among other issues, the study tests a narrative that has circulated suggesting that patent monetization creates for venture capital investment. According to the theory, venture capitalists will be attracted to the possibility of monetizing a startup company's patents if the company fails, and this attraction spurs investment. The study tests that narrative through the eyes of the venturebacked community itself.

Results include the following: When making funding decisions, the vast majority of venture capitalists do not consider the potential for selling to assertion entities if the company fails. Thus, patent monetization does not appear to provide investment incentives. In addition, both the companies and the venture capitalists overwhelming believe that patent demands are having a negative impact on the startup community, and all or most of the demands they experience are coming from those whose core activity involves licensing or litigating patents. The effects of these demands are described in terms including the specific costs expended by the companies and the distraction to management, engineers, and other employees. Most important, participants detail the human toll that patent demands have had on entrepreneurs.
\end{abstract}

\footnotetext{
* Professor of Law, Harry \& Lillian Hastings Chair and Director of the Institute for Innovation Law at the University of California Hastings College of the Law. This work was supported by the University of California Hastings Institute for Innovation Law. No corporation or other entity outside of UC Hastings provides more than $10 \%$ of the Institute's funding. The National Venture Capital Association has provided no funding for this or any other work conducted by the author. I am grateful to Colleen Chien, Jennifer Dowling, Ira Ehrenpreis, Osagie Obasagie, Carolyn Spencer, and Kelly Stone for their suggestions on the design of the study. I also wish to thank Sara Jeruss, David Schwartz and Michael Risch for their comments on the results, as well as Alice Armitage, Kristy Brady, Jake Wexler, and Josh Wolf for their invaluable research assistance.
} 
I. OVERVIEW OF THE STUDY............................................................ 237

A. Background on Modern Patent Monetization ............................. 238

B. Key Study Results ................................................................. 242

C. Choosing Terms and Points of Measurement: A Politically

Charged Endeavor .......................................................................... 244

D. Brief History and Overview of Startup Financing ...................... 254

E. Design of Study and Participants............................................. 258

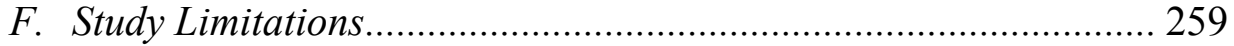

G. General Characteristics of Respondents....................................... 261

II. RESULTS ........................................................................................... 263

A. The Extent of Patent Demands Against Venture-Backed

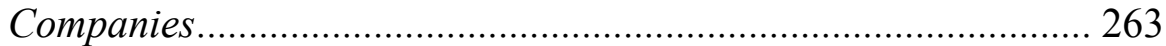

B. Source and Timing of Demands ............................................... 266

C. Significance and Cost of Impact of Patent Demands on Venture-Backed Startups.......................................................... 268

D. The Human Factor: Respondents Elaborate on the Impact of

Patent Demands .......................................................................... 272

1. Extraordinary Impacts ....................................................... 272

2. Distractions to Management and Engineers......................... 273

3. Cost Impact .................................................................... 273

4. The Human Face ................................................................... 274

5. Other Assorted Impacts......................................................... 275

6. Weak Claims; Wasteful Process .......................................... 275

E. Is Patent Assertion Helpful or Harmful for the

Venture-Backed Community? .................................................... 276

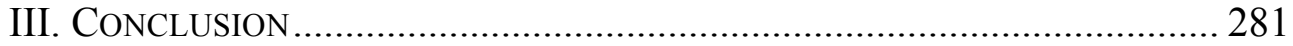

\section{OVERVIEW OF THE STUDY}

This article presents the results of a study conducted on the topic of patent demands against venture-backed startups. The study was conducted through the members of the National Venture Capital Association and their portfolio companies. ${ }^{1}$ The article details responses from more than 200 venture capitalists and their portfolio companies. Results include

\footnotetext{
${ }^{1}$ This study was conducted by a law professor and was supported by the professor's academic institute. See author's note.
} 


\section{PATENT DEMANDS \& STARTUP COMPANIES}

quantitative information on the frequency of patent demands, ${ }^{2}$ the percentage of demands that came from those whose core business involves licensing or litigation patents, the costs of responding to demands, the possibility of demands timed in relation to funding, and the distribution of demands in different industry sectors.

Results also include the respondent's views on whether patent demands are a significant problem in the sector, whether venture capitalists consider the possibility of selling patents in determining whether to invest in a company, and whether venture capitalists would be deterred by patent demands against a company they were considering adding to their portfolio. Finally, the article provides qualitative information on the effects of patent demands on the lives of venture-backed startup companies-documenting both the human and the economic costs of patent demands.

\section{A. Background on Modern Patent Monetization}

Patent monetization has existed in some form since at least the 19th century. In recent years, however, the market for patent trading and patent assertion has expanded dramatically, growing both in scope and in the level of sophistication. As a result, the percentage of patent lawsuits filed by those who do not make products has increased dramatically from roughly $25 \%$ in 2007 to almost $60 \%$ in $2012 .^{3}$ In other words, as of 2012 the majority of patent lawsuits are filed by those whose core business involves licensing and litigating patents as opposed to making products.

Before the rise of the today's patent assertion market, most patent litigation operated more as a tool of last resort which was primarily used by companies that created their own products against other companies that also created products. In this context, the threat of litigation ensured a form of mutually assured destruction. For example, if one product company launched its patents against a competitor, the target company would wield its own set of patents in retaliation, putting the original company's products at risk. The tendency toward risk aversion, acted as a limiting factor on patent demands and patent lawsuits.

\footnotetext{
${ }^{2}$ For purposes of this study, "patent demands" include letters indicating that the recipient may be infringing a patent and demanding a license fee, threats of litigation, or lawsuits. ${ }^{3}$ See Robin Feldman, Tom Ewing \& Sara Jeruss, The AIA 500 Expanded: The Effects of Patent Monetization Entities, 18 UCLA J.L. \& TECH. 1 (2013); see also Colleen V. Chien, Patent Assertion Entities, Presentation to the DOJ/FTC Hearing on PAEs (Dec. 10, 2012) http://papers.ssrn.com/sol3/papers.cfm?abstract_id=2187314 (using data from RPX Corporation and concluding that the percentage of litigation by non-practicing entities in 2012 has reached $62 \%$ ).
} 
In today's patent assertion market, however, entities that do not make products use litigation as a profit-generating weapon, often relying on a product company's fear of the high costs and risks of patent litigation to encourage settlements. The complexity and uncertainty of the patent system tends to work in favor of those who do not make products. For example, it is tremendously difficult to know what the language of a patent covers, and it can cost as much as $\$ 6$ million to find out through a patent lawsuit. When a patent holder brandishes numerous patents at once, this cost and complexity can multiply. Moreover, if a product company challenges the patent and loses, the company could face enormous damages and litigation costs, as well as the possibility that its product could be shut down entirely. A rational company, therefore, may choose the less expensive option of settlement-still a bitter pill to swallow, but one that tastes far better than the costs and risks of litigation.

The cumulative impact of patent assertion in its various forms is staggering. Although difficult to measure with any accuracy, scholars have estimated that patent assertion by monetizers cost U.S. companies $\$ 29$ billion in 2011 alone. $^{4}$ These estimates suggest that only $20 \%$ of that cost flows back to innovation, either to outside inventors or to any internal research and development by monetizers. ${ }^{5}$

Other scholars have considered different aspects of patent assertion and monetization. Professor Brian Love has determined that non-practicing entities (one of many terms for those who do not make products) file more than twice as many lawsuits per patent as product companies and sue more than four times as many alleged infringers per patent. ${ }^{6}$ Others have found evidence that patent monetization lawsuits are directed most frequently at companies in the Internet and technology sectors. In particular, Professors Allison, Tiller, Zyontz, and Bligh have examined internet-related patents and non-internet-related patents, concluding that the internet-related patents have been litigated 7.5 to 9.5 times more frequently than patents not related to the Internet. ${ }^{7}$ Professor David Schwartz has noted that costs differ between plaintiffs and defendants in certain types of patent lawsuits, which he attributes to the fact that non-practicing entities can keep costs low by having few documents to discover, moving to trial sparingly, and avoiding

\footnotetext{
${ }^{4}$ See James E. Bessen \& Michael J. Meurer, The Direct Costs from NPE Disputes, 99 CORNELL L. REV. (forthcoming 2014).

${ }_{6}^{5}$ See id.

${ }^{6}$ Brian J. Love, An Empiricial Study of Patent Litigation Timing: Could A Patent Term Reduction Decimate Trolls Without Harming Innovators? (Santa Clara Univ. School of Law, Working Paper No. 1917709, 2011-12).

${ }^{7}$ John R. Allison et al., Patent Litigation and the Internet, 2012 StAn. TeCH. L. REV. 1, 6 (2012).
} 


\section{PATENT DEMANDS \& STARTUP COMPANIES}

bringing motions in court. ${ }^{8}$ Professor Michael Risch studied the 10 most litigious non-practicing entities and concluded that most of the patents asserted in the sample originated from product companies. ${ }^{9}$ Others have looked at "sport of kings" patent suits, involving companies with more than $\$ 100$ million in revenue, and still others have examined patent suits between smaller entities. ${ }^{10}$

Of particular interest, Professor Colleen Chien has recently studied startups and patenting, including interviews with patent litigators, largecompany patent attorneys, venture capitalist, and startups. ${ }^{11}$ Although the work has focused particularly on experiences with non-practicing entities, Chien also examined views on obtaining patents and interactions with larger product companies. Her conclusions include that only $5 \%$ of startups in the sample had sold patents to non-practicing entities, that small companies are vulnerable targets when - because of a lack of leverage - they pay nuisance settlements regardless of the merits, that small companies are often targets of patent suits because they are users of technology, and that costs are highest for startups when the primary response involves fighting in court. ${ }^{12}$ Where aspects of Chien's examination can be compared to the work of this study, the results will be described below.

The problem of patent monetization also has attracted increasing attention from the press and companies in many sectors. Technology companies have led the way, with active lobbying campaigns in the United States as well as in Europe. ${ }^{13}$ This is not surprising, given that modern patent trolling has had perhaps the largest impact on technology-heavy

\footnotetext{
${ }^{8}$ David Schwartz, The Rise of Contingent Fee Representation in Patent Litigation, 64 ALA. L. REV. 335 (2012).

${ }^{9}$ See Michael Risch, Patent Troll Myths, 42 Seton Hall L. Rev. 457 (2012). The list was provided by PatentFreedom, which identifies itself as offering subscriptions and services to help operating companies and law firms manage NPE risk more effectively. See https://www.google.com/search? $q=$ PatentFreedom\&aq $=f \& o q=$ pat\&aqs $=$ chrome $.0 .59 j 57 j$ 6013j61.1323\&sourceid=chrome\&ie $=U T F-8$.

${ }^{10}$ See Colleen V. Chien, Startups and Patent Trolls, Report from the New America Foundation's Open Technology Institute, http://ssrn.com/abstract=2146251 (citing GWENDOLYN BALL \& JAY KESAN, TRANSACTION COSTS AND TROLLS: INDIVIDUAL InVENTORS, SMALl FIRMS AND ENTREPRENEURS IN PATENT LitigATION 13 (2009); Colleen V. Chien, Of Trolls, Davids, Goliaths, and Kings: Narratives and Evidence in the Litigation of High-Tech Patents, 87 N.C. L. REV. 1571 (2009)).

${ }^{11}$ Different aspects of Chien's work on patents and startups are available in two locations: Chien, Patent Assertion Entities, supra note 3, and Chien, Startups and Patent Trolls, supra note 10 .

${ }^{12}$ See id.

${ }^{13}$ Letter from adidas. AG, et al. to Preparatory Committee, Unified Patent Court, Member States of the European Union (Sept. 26, 2013), http:/graphics8.nytimes.com/packages/pdf/business/26trolls-letter.pdf.
} 
industries such as software, smartphones, and computers. Others have joined the chorus of complaints, including coffee shops, hotels, and retail outlets large and small. Furthermore, the research below suggests that patent monetization is beginning to expand beyond the tech industry, entering the life sciences arena. In short, patent monetization is a complex and troubling problem that is reaching into a variety of sectors, although the primary impact continues to be felt in technology.

In response, legislators and regulators at both the state and federal level have begin exploring solutions to the problem. A variety of bills have been introduced in Congress, including an extensive reform bill introduced by Congressman Goodlatte, Chairman of the House Judiciary Committee. The bill was passed by the House of Representatives in December of 2013. ${ }^{14}$ Furthermore, a bill empowering the Federal Trade Commission to combat aggressive patent assertion was introduced in the Senate by Senators McCaskill and Rockefeller. ${ }^{15}$ The Federal Trade Commission itself, which held a joint workshop on patent monetization with the Department of Justice in December of 2012, voted in the fall of 2013 to initiate a broad-ranging economic investigation into 25 patent assertion entities. ${ }^{16}$ In addition, the White House issued a report on patent assertion in the summer of 2013, along with a series of executive orders. ${ }^{17}$ In response to those orders, as well as workshops held on the topic, the Patent and Trademark Office has begun exploring sunshine rules for disclosure of patent ownership. State legislators and attorneys general have joined in, taking actions against monetizers who have targeted companies in their jurisdiction. ${ }^{18}$ Even the Supreme Court has agreed to hear several cases peripherally related to the topic. ${ }^{19}$

\footnotetext{
${ }^{14}$ Innovation Act, H.R. 3309, 113th Cong. (2013) (a bipartisan bill aimed at combating abusive patent litigation).

${ }^{15}$ Transparency in Assertion of Patents Act, S. 2049, 113th Cong. (2014) (aimed at curbing unfair and deceptive practices arising in connection with the assertion of patents).

${ }^{16}$ See FTC, Agency Information Collection Activities; Proposed Collection; Comment Request, 78 FR 61,352 (Oct. 3, 2013), http://www.ftc.gov/os/fedreg/2013/10/131003agencyinfofrn.pdf.

${ }^{17}$ See Executive Office of The President, PATENT Assertion And U.S. INNOVATION (June 2013), http://www.whitehouse.gov/sites/default/files/docs/patent_report.pdf.

${ }^{18}$ In February of 2014, forty-two attorneys general signed a letter to Congress supporting federal patent reform legislation. Many states have also begun creating causes of action against patent trolls under state law. Vermont has been one of the leaders in this area: the Vermont state legislature passed a bill, Bad Faith Assertions of Patent Infringements, H.B. 299, to be codified at VT. STAT. ANN. tit. 9, §§ 4195-4199 (2013). In addition, the Vermont Attorney General filed a complaint against MPHJ Technology, alleging that MPHJ engaged in unfair and deceptive practices when it sent letters threatening patent
} 


\section{PATENT DEMANDS \& STARTUP COMPANIES}

With the high level of interest in patent monetization and its effects on US companies, data on the topic is increasingly important. This study is intended to examine a small corner of the question and to test narratives about startups and the rising patent monetization market. With this goal in mind, the study examines patent demands against startup companies through the experiences of venture capitalists and their portfolio companies. In particular, the study tests a narrative that has circulated suggesting that patent monetization creates incentives for venture capital investment. ${ }^{20}$ The study tests this narrative through the eyes of the venture-backed community itself, and examines the community's general experiences with and perspectives on patent demands in general.

\section{B. Key Study Results}

Key results of the study are the following:

- $70 \%$ of the venture capitalists have portfolio companies that have received patent demands, and roughly one in three startup companies report receiving patent demands.

- Although $70 \%$ of the venture capitalists have experienced demands in the information technology sector, 30\% also have experienced demands in the life science sector.

- The vast majority of patent demands against the startup companies come from entities that license or litigate patents as their core activity. (Specifically, $59 \%$ of the venture

\footnotetext{
litigation to small businesses and non-profits in the state. The Oregon Senate passed S.B. 1540 (Feb. 19, 2014) (making patent trolling a violation of the state's Unlawful Trade Practices Act). In Wisconsin, the legislature passed S.B. 498 (Mar. 21, 2014) (making it a crime to send patent-licensing demand letters that contain false or misleading information). In New York, the state Attorney General entered into a settlement with MPHJ (restricting the patent assertions activities within the state of New York).

${ }^{19}$ Icon Health \& Fitness, Inc. v. Octane Fitness, LLC, 496 F. App'x 57 (Fed. Cir. 2012), cert. granted sub nom Octane Fitness, LLC v. Icon Health \& Fitness, Inc., 134 S. Ct. 49 (2013); Highmark, Inc. v. Allcare Health Mgmt. Sys., Inc., 687 F.3d 1300 (Fed. Cir. 2012), cert. granted 134 S. Ct. 48 (2013); CLS Bank Int'l v. Alice Corp. Pty 717 F.3d 1269 (Fed. Cir. 2013), cert. granted 134 S. Ct. 734 (2013).

${ }^{20}$ See Edith Ramirez, Chairwoman, FTC, Opening Remarks, Competition Law \& Patent Assertion Entities: What Antitrust Enforcers Can Do, (June 20, 2013) (suggesting, in a list of positive attributes of patent assertion entities, that such entities, "can make it easier for a failed start-up to monetize its patents, providing some insurance for venture capitalists"), available at http://www.ftc.gov/speeches/ramirez/130620paespeech.pdf.
} 
capitalists and $66 \%$ of the startup companies reported that all or most demands come from such entities.)

- $74 \%$ of the venture capitalists and $58 \%$ of the startup companies report that patent demands had a significant impact on a company. (Details of those impacts and associated costs are described below);

- According to the vast majority of both the venture capitalists and the startup companies, the costs of preparing for and defending against patent demands exceed $\$ 50,000$ per company, with a number of companies reporting costs in the millions of dollars.

- $64 \%$ of venture capitalists disagree with the statement, "as a venture capitalist, I consider the potential for selling patents to patent assertion entities if the companies fail."

- When asked whether they see patent assertion as positive for startups and the startup community, $72 \%$ of venture capitalists disagree.

- $100 \%$ of venture capitalists indicate that if a company had an existing patent demand against it, they might refrain from investing. Roughly half indicate that it would be a major deterrent on its face, and the other half indicate that they might refrain, depending on the circumstances.

Finally, to paraphrase one venture capitalist who summed up the impact of patent demands on venture-backed companies in a particularly cogent fashion: When companies spend money protecting their intellectual property position, they are not expanding; and when companies spend time thinking about patent demands, they are not inventing. ${ }^{21}$

\footnotetext{
${ }^{21}$ The venture capitalist's direct quotation from the study comments is the following: "More spend [sic] to protect IP position, not necessarily expand. Thinking about trolls asserting not about inventing."
} 


\section{PATENT DEMANDS \& StARTUP COMPANIES}

\section{Choosing Terms and Points of Measurement: A Politically Charged Endeavor}

An initial question in any survey involves the terms to use and the issues to be measured. As concerns have escalated over the problem of patent trolling, everyone has scrambled to define terms. In this highly charged atmosphere, no one wants to be branded a bad guy, and if patent trolls are bad guys, everyone wants the definition to point somewhere else. And, indeed, numerous definitions - and variations of those definitionshave been offered to define the notion of patent trolling. As a result, seemingly arcane disagreements over the terms of measurement can have a significant effect on the legislative and regulatory rules chosen to address inappropriate use of patents, as well as the business models that develop in anticipation of or in response to those legal regimes. Words matter, and never more so than in the current political climate. Thus, the following section will describe the different terms and definitions that have been suggested by various scholars, commentators, and market actors and explore the theoretical bases for each. The section will also explain the parameters chosen for this study and the logic behind those choices.

In discussing the topic of patent assertion, many have used the term non-practicing entity, or NPE, to describe entities that do not use the patents they own to create anything. In the code-like language of patents, using the ideas in the patent to create a product is called "practicing the patent," and thus, those who do not create products are called "non-practicing." Among many others, Congress used the term NPE in directing the non-partisan General Accounting Office to study patent assertion. ${ }^{22}$

Problems with the term NPE include the question of whether to incorporate universities in the definition. Universities are in the business of scientific research and education, and they generally do not engage in the production of products from their inventions. Thus, they do not actually practice the ideas in their patent portfolios. Universities, however, traditionally do not engage in extensive patent litigation, filing only onehalf of one percent of all patent lawsuits in a recent four-year period, for example. ${ }^{23}$ Thus, they do not appear to engage in the same types of behavior as other entities that do not practice their patents.

\footnotetext{
${ }^{22}$ See Leahy-Smith America Invents Act, Pub. L. No. 112-29 § 34 (2011) (directing the nonpartisan General Accounting Office to study the effects of non-practicing entities on U.S. patent litigation); see also 157 CONG. REC. S5441 (daily ed. Sept. 8, 2011) (statement of Sen. Patrick Leahy).

${ }^{23}$ See Feldman, Ewing \& Jeruss, supra note 3, at 41.
} 
In addition to issues related to universities, the term non-practicing "entity" could be interpreted to include only those who are organized in a particular manner - a limitation that could be problematic. Some of the most famous modern examples of those whose core activity is patent assertion are individuals, rather than entities. ${ }^{24}$ Other prolific monetizers are organized as trusts. ${ }^{25}$

The distinction between "entities" and "non-entities" has led to confusion, particularly with the GAO report on patent assertion. In measuring lawsuits filed by what it termed "patent assertion entities," the report noted a significant, but smaller, increase in lawsuits from such entities than was noted by other studies. Much of the difference between the studies can be attributed to the GAO methodology, which included in its numbers only those organized as corporations or partnerships but not those organized as trusts or operating as individuals. ${ }^{26}$ This led to some odd results. For example, the greatest number of lawsuits filed in the GAO's own 500 case sample was filed by someone organized as a trust. ${ }^{27}$ A wellknown name in patent assertion circles, the business activity of this trust is licensing and litigating patents. Nevertheless, the GAO excluded this trust from the count of patent assertion entities, as well as excluding other trusts and individuals engaged in the same activity.

The reverse definitional problem occurred early on when some researchers defined patent trolls only as individuals. In particular, one of the earliest data-based analyses of modern patent trolling looked only at individual inventors. ${ }^{28}$ Focusing only on the individuals, however, ,misses much of the activity.

From a definitional standpoint, it should not matter whether one chooses to organize oneself as a corporation, a partnership, a trust, or simply to act as an individual. It is the activity that matters. ${ }^{29}$ Thus, in

\footnotetext{
${ }^{24}$ See, e.g., David Segal, Has Patent, Will Sue: An Alert to Corporate America, N.Y. TIMES (July 13, 2013), http://www.nytimes.com/2013/07/14/business/has-patent-will-sue-an-alertto-corporate-america.html (profiling Erich Spangenberg).

${ }^{25}$ See Sara Jeruss, Robin Feldman \& Joshua Walker, The America Invents Act 500: Effects of Patent Monetization Entities on US Litigation, 11 DUKE L \& TECH. REV. 357, 382 (2012) (analyzing the data that the authors provided to the GAO).

${ }^{26}$ See United States Government Accountability Office Report, Intellectual Property: Assessing Factors That Affect Patent Infringement Litigation Could Help Improve Patent Quality, at 17 n.35 (August 2013) (noting the exclusion of individuals and trusts and the resulting variation from the Feldman, Ewing \& Jeruss, supra note 3).

${ }^{27}$ See id.

${ }^{28}$ See James Bessen \& Michael J. Meurer, PATent FaILuRe 16 (2008).

${ }^{29}$ One could argue that certain organizational formations facilitate so-called trolling behavior more smoothly, for example, by limiting the targets ability to respond. We see
} 


\section{PATENT DEMANDS \& STARTUP COMPANIES}

studying the venture-backed community, I used a definition that included all whose core business activity involves licensing or litigating patents as opposed to making products. The definition, therefore, includes not just those organized as a corporation or partnership but also those organized as trusts or operating as individuals.

The GAO's term, "patent assertion entity," raises other difficulties as well. The term patent assertion entity, or PAE, focuses on entities whose primary activity is to purchase patents to make licensing demands against others who make products - in other words, to "assert" their patents. The Federal Trade Commission in particular has used the term PAE. ${ }^{30}$ The term, however, is subject to additional confusion. For example, does the notion of an "assertion entity" include only those who file lawsuits or does it also encompass those who assert by making licensing demands short of filing a lawsuit? Some entities have tried to suggest that those who assert only through licensing demands should be excluded from the term "patent assertion entity." For example, the patent aggregator RPX buys patents, grants licenses to those who purchase the rights to their portfolios, but reserves the right to transfer those patents to others - subject to the licenses. In other words, those who might buy the patents could sue anyone other than companies who have already purchased a license from RPX. Although the buyer's patents may file infringement lawsuits, RPX does not file any lawsuits itself.

In press interviews, RPX officials have noted that they have sold patent rights only infrequently, and have explained the rational for those sales. For example, they describe using the practice to drive reluctant parties to join the RPX network and avoid free rider costs. ${ }^{31}$ In addition, RPX

this as more central to issues related to the effectiveness of the behavior, rather than as a reason to alter the definition.

${ }^{30}$ FTC, The Evolving IP Marketplace: Aligning Patent Notice And Remedies With Competition 8 at n.5 (2011), www.ftc.gov/os/2011/03/110307patentreport.pdf [hereinafter Evolving IP Marketplace] (defining PAE as having a business model focused on "purchasing and asserting patents against manufacturers already using the technology, rather than developing and transferring the technology"); see also Ramirez, supra note 20.

${ }^{31}$ A Fortune Magazine feature story on RPX reported on RPX's sales to other NPEs. The story quotes John Amster, CEO of RPX:

The practice is used in part, Amster admits, to drive prospects into the network that otherwise feel no need, because RPX, at the behest of their competitors, has already purchased the portfolios that most threaten their industry sector. Such prospects sometimes claim to see no value in the portfolios RPX has already purchased. "We all them back a few months later," Amster says, "and say, 'Look. We put it up for sale. There's an 
purchases patents from NPEs that have already filed lawsuits, buying a license for existing RPX clients and an option for the remaining defendants. RPX then approaches the remaining defendants, offering to buy them out of the lawsuit in exchange for joining RPX. ${ }^{32}$

Distinguishing between those who assert by licensing demands and lawsuits as opposed to those who assert only by licensing demands would be problematic. From a practical perspective, much of the patent assertion activity occurs outside of litigation, and studies estimate that $90 \%$ of demands for a patent license never proceed all the way to a lawsuit, presumably because either the target agrees to pay a fee or the demand is dropped. ${ }^{33}$ All of these demands, however, occur in the shadow of a potential lawsuit. ${ }^{34}$ A license, after all, is merely an agreement not to sue in return for a monetary payment, and the threat of a lawsuit is what drives companies to pay the licensing fee. Thus, in examining patent assertion behavior it makes little sense to look only at assertions that progress all the way to the particular moment of filing a lawsuit, rather than the other assertions that take place in the shadow of that filing.

From an economic perspective as well, there may be very little difference between those who file lawsuits and those who do not-at least if those who do not file lawsuits are willing to transfer patents to others who will file suit or to purchase patents out of existing lawsuits. Imagine an entity that chastely refuses to file any lawsuits, but sells its patents to or buys its patents from hypothetical nasty third parties, who do sue. The price of the patent when it is sold reflects the expected value of the lawsuit. Thus,

NPE who's willing to pay us for it." And sometimes they say, 'You're no different than they are' [likening RPX to the trolls.] And we say, 'Hey, wait a minute. Back up. We bought this on behalf of our clients. You told us there was no value to it. The market has spoken, and there is value. Somebody is going to sue you. We didn't call them and tell them to sue you. We said, 'Here's an asset. It's for sale.' If you don't think it's a risk, then fine."

Roger Parloff, Taking on the Trolls, FORTUNE (March 17, 2014).

${ }^{32}$ See id.

${ }^{33}$ See Feldman, Ewing \& Jeruss, supra note 3, at 32. The study notes that the 2013 White House Report on Patent Assertion cites conservative estimates of the number of patent threats in 2012 at 60,000 with the actual number more likely over 100,000. Comparing even the more conservative number of patent demands with the roughly 5,000 lawsuits filed in 2012, one can conclude that more than $90 \%$ of patent demands do not reach the courthouse door.

${ }^{34}$ The concept of bargaining in the shadow of the law is introduced and explored in the seminal article, Robert H. Mnookin \& Lewis Kornhausert, Bargaining in the Shadow of the Law: The Case of Divorce, 88 YALE L.J. 950 (1979). 


\section{PATENT DEMANDS \& STARTUP COMPANIES}

the chaste entity receives the economic benefit of that lawsuit, even without having to file the suit itself. Moreover, the chaste entity's licensing activity benefits from the possibility of sale to those who will sue. In other words, target companies are encouraged to buy licenses from the chaste entity for fear that they will have to face a lawsuit from the nasty third party who might buy the patent. The threat, implicit or explicit, is that if one does not join the club, one will be left out in the cold as the only target available for the nasty third party to sue. ${ }^{35}$ The same is true when the chaste entity purchases patents out of already existing lawsuits. The chaste entity may be able to provide benefit from economies of scale or repeat experience, but once again, it benefits from a system in which patent lawsuits are filed and from the economic pressure of the costs and risks of the litigation, even though it does not file lawsuits directly itself. In short, a distinction between those whose assertion profile includes lawsuits and those whose assertion profile does not makes little sense practically or economically.

The FTC avoids this problem, defining patent assertion entities to include those who assert by licensing demands as well as those who assert by lawsuits, but the agency adds its own variation on the theme. The FTC defines patent assertion entity to include only those who purchase and assert patents, the implication being that one who originally obtained the patent would be excluded. ${ }^{36}$ In other words, those who obtain patents and assert them are not included in the definition of patent assertion entities. In particular, the definition would exclude entities in the semi-conductor industry - such as Qualcomm and Rambus - that spend large sums researching and designing products. ${ }^{37}$ Companies such as these may create prototypes to license others to produce but do not actually manufacture the product themselves. These entities have argued fervently that they should not be considered part of any definition of patent troll.

Some Congressional proposals contain a variant of this approach. They would exempt those who have expended significant resources in attempting to work the patent from provisions related to curbing patent assertion abuse.

\footnotetext{
${ }^{35}$ For an allegation that entities like RPX make this threat explicit, see Tom Ewing \& Robin Feldman, The Giants Among Us, 2012 STAN. TECH. L. REV. 1, 29-30 (citing letter to the FBI from Kaspersky Labs). In press interviews, RPX notes that it has sold rights only infrequently.

${ }^{36}$ See id.

${ }^{37}$ See Daniel Culley et al., Learning from Rambus-How to tame those troublesome trolls, 57 ANTITRUST BULL. 117 (2012) (using both Rambus and Qualcomm as examples of corporations that invent and produce patented products and subsequently take steps to monetize the patents they've obtained).
} 
This definitional issue is perhaps the most challenging, and it deserves considerable exploration. To the extent that society is concerned about those who assert patents as a business practice without contributing to the creation of products for society, the semi-conductor companies have a point. Engaging in significant research and development that leads to the creation of a viable product should be considered a productive activity, even if the company chooses to hire others to do the actual manufacturing. Economists generally would frown on a rule that preferences vertical integration - in other words, they would reject a rule providing incentives for one company to engage in all the levels of production necessary for a final product.

Nevertheless, defining patent assertion entities as only those who buy and assert patents risks omitting a significant amount of activity that could look much like the remainder of what falls within the definition. In addition, the more limited definition implies that original patent holders should be omitted from the legislative and regulatory reform proposals that may be developed to address modern concerns about the inappropriate use of patents. This, in turn, suggests that original patent holders are unlikely to create the types of problems that are fueling current patent trolling concerns.

The logic behind such a conclusion is questionable, however, when one considers the following. The patent system has operated for some time with a high percentage of rights that are never actualized. ${ }^{38}$ These shadow rights have remained largely on the periphery of the patent system, creating no direct returns for the patent holder. In fact, studies suggest that more than $90 \%$ of patents never create a direct return for the patent holder. ${ }^{39}$

Many of these patents may be of questionable value. The Patent \& Trademark Office lacks the resources to examine the massive number of patent applications that come through its doors - not with the level of scrutiny required to eliminate weak patents, or weak claims within a patent. For example, one scholar has estimated that patent examiners spend no more than 18 hours on any patent application, and this time is likely to be

\footnotetext{
${ }^{38} \mathrm{I}$ have described the issue of shadow rights, and problems with monetization of those rights, in greater detail. See Robin Feldman, Intellectual Property Wrongs, 18 STAN. J.L. Bus. \& Fin. 247, 261-63 (2013). That discussion is summarized here.

${ }^{39}$ Gideon Parchomovsky \& R. Polk Wagner, Patent Portfolios, 154 U. PA. L. REV. 66 (2005) (noting that estimates suggest that less than 5 percent of patents hold any value). See also Edmund W. Kitch, The Nature and Function of the Patent System, 20 J.L. \& ECON. 265, 267 (1977).
} 


\section{PATENT DEMANDS \& STARTUP COMPANIES}

spread over two to three years. ${ }^{40}$ With patent applications containing dozens or even hundreds of claims, the available time is simply insufficient.

It is not just the patent as a whole that may be weak. Even if some claims within the patent have merit, others may be of questionable validity. Patent drafters frequently write a range of claims, including very aggressive, broadly reaching claims down to much more narrow and specific ones. ${ }^{41}$ Patent examiners may cull out some of the overbroad and weaker ones, but with the limited time available to review each patent, examiners are not likely to catch all weak claims. Nevertheless, each individual claim can be launched on its own against a target company.

The system may have worked reasonably well when fewer patents were operationalized. Rather than concentrating resources up front, the legal system could focus its energy on the few patents that became valuable enough to make it to litigation. ${ }^{42}$ In a system of intense monetization, however, every patent, and every claim within each patent, has the potential to be launched against product manufacturers to garner a return. Thus, the fact that the patent being asserted was written by the patent holder is no guarantee that it is better than any other patent.

Moreover, exempting those who have originated the patent could have the effect of merely altering how the patent assertion business is organized. For example, rather than purchasing a patent from the original patent holder, the monetizer could simply join forces with the original inventor, either using the patent holder as a front for the monetization activities or simply funding monetization efforts by the patent holder in exchange for a healthy share of the returns. In that manner, the monetizer has now escaped the definition of "one who purchases and asserts patents" simply by not purchasing. The market has already developed complicated schemes in which product companies or aggregators fund the monetization activities of others, along these lines.

\footnotetext{
${ }^{40}$ Mark A. Lemley, Rational Ignorance at the Patent Office, 95 Nw. U. L. REV. 1495, 1500 (2001).

${ }^{41}$ See Robin Feldman, Rethinking PATEnt LAw 40-74 (2012) (describing how modern patents operate).

${ }^{42}$ See id.; see also Christian Bessy \& Eric Brousseau, Technology Licensing Contracts: Features and Diversity, 18 InT'L REV. L. \& ECON. 451, 459 (1998); Eric Brousseau \& Christian Bessy, Public and Private Institutions in the Governance of Intellectual Property Rights, in Intellectual Property Rights: InNOvation, Governance, AND THE Institutional EnVIRONMENT 251 (Birgitte Andersen, ed., 2006); Dan L. Burk \& Mark A. Lemley, Policy Levers in Patent Law, 89 VA. L. REV. 1575 (2003); F. Scott Kieff, The Case for Registering Patents and the Law and Economics of Present Patent-Obtaining Rules, 45 B.C. L. REV. 55 (2003); Kelly Casey Mullally, Legal (Un)Certainty, Legal Process, and Patent Law, 42 LoY. L.A. L. REV. 1109 (2010).
} 
In addition, monetizers and aggregators could simply choose to get into the business of filing for patents. Thus, if we choose to define patent assertion entities to exclude those who file for patents, we could be inadvertently incentivizing the creation of an industry of applying for patents for the purpose of monetizing them, rather than for the purpose of creating products for society.

There is an even more subtle issue, however, involved in exempting the original patent holder from the definition of monetization. As a society, we have a romantic attachment to the notion of the inventor, which spills over into a romanticized image of those who hold patents. I have described this romanticized image in the following manner:

In the classic story of invention, a great thinker toils to create a wonderful innovation, files for a patent to protect what he or she has contributed to the store of human knowledge, and then produces a new product that enters the market, improving the lives of all citizens. In a variation on this theme, the valiant inventor, deeply immersed in the pursuit of innovation, lacks the capital, experience or interest to commercialize the invention. The inventor then simply licenses the patent to a third party, who brings forth the product for the betterment of society. Copyright tells a similar tale that features brilliant writers hunched over coffeehouse tables, or dedicated computer programmers toiling late into the night, accompanied only by caffeine and their dreams. ${ }^{43}$

It is a lovely story, and one that undoubtedly exists to some extent, but much of the modern patent world looks nothing like this.

In particular, most people assume that a patented invention can create a product. This assumption could not be farther from the truth. Most products require a multitude of intellectual property in order to create a viable product. Such intellectual property may include numerous patents, as well as trade secrets and those wonderfully named components, "know how" and "show how." Even if the knowledge captured in the patent can be translated successfully into a product, that product must be developed further into a form that is stable and can be mass produced and distributed, which requires additional intellectual property, knowledge, and skill. The gap between a patented idea and a viable product is known colloquially as

\footnotetext{
${ }^{43}$ Robin Feldman, Intellectual Property Wrongs, 18 STAN. J. L. BUS. \& FIN. 250 (2013); Mark A. Lemley, The Myth of the Sole Inventor, 110 Mich. L. REV. 709 (2012).
} 


\section{PATENT DEMANDS \& STARTUP COMPANIES}

the "valley of death," a valley that only a few hardy souls are able to cross. Thus, most patent holders who try to develop a product are destined to become failed entrepreneurs.

Psychology research suggests that we often assess items as having greater value when they belong to us than when they belong to someone else. ${ }^{44}$ In addition, anyone who has ever represented a client can attest that clients generally believe their claim is right, a perspective that cannot possibly be accurate for all sides at all times. Such selective reasoning can be explained by the coherence effect, a psychological phenomenon under which people who examine a heterogeneous set of facts are likely to make inferences that are shaped by their own biases and preferred conclusions. ${ }^{45}$ Even if people begin their reasoning processes by looking for facts that support both sides of an argument, the underlying tendency toward biased reasoning can lead to a variety of subconsciously selective behaviors. ${ }^{46}$ This includes framing one's research inquiries in a way that only pulls in favorable evidence (a selective framing strategy) and choosing only the evidence that is likely to support a particular hypothesis (selective exposure). $^{47}$

One might anticipate that these types of distortions would be enhanced by those who are not repeat players and who have less experience in the arcane world of patent law, a description likely to apply to many individual inventors. Our fascination with the romanticized individual inventor could inadvertently fuel a cottage industry. Failed entrepreneurs, which most entrepreneurs are likely to be, would be encouraged to turn to patent assertion as a second career - a career that would provide a handy outlet for frustration over the inability to get a product off the ground. With monetizers willing to join forces and fund these efforts behind the scenes, if we exempt original patent holders from the definition of monetizers, we may simply shift the current modes of monetization-with all of their

\footnotetext{
${ }^{44}$ See, e.g., Ziv Carmon \& Dan Ariely, Focusing on the Foregone: How Value Can Appear So Different To Buyers And Sellers, 27 J. CONSUMER RES. 360 (2000).

${ }^{45}$ Dan Simon, In Doubt: The Psychology of the Criminal Justice Process, 34-35 (2012).

${ }^{46} I d$. at $36-37$.

${ }^{47}$ Id. at 37 . See also id. at 38. (Selective scrutiny $[:]$. . . [R] esearch demonstrates that people tend to scrutinize information that is incompatible with their conclusion, but apply lax standards when assessing the validity of compatible information . . . Biased evaluation $[:]$... [T] he most ubiquitous form of biased reasoning occurs through a distorted evaluation of evidence ... . Selective stopping [:] . . [A] limited body of research suggests that people tend to shut down inquiries after having found a sufficient amount of evidence to support their leading hypothesis.) (Citations omitted).
} 
problems - into a different form. Rather than curbing abuses, the result could be the same monetization with a different face.

Exempting original patent holders may reflect concerns about problems that small players face in the patent system, and small players are certainly at a disadvantage in the expensive and complex world of patents. Some small companies and individual inventors have complained that large companies are less than diligent, to put it mildly, in responding to complaints that rights are being trampled. Rights, of course, are useless if one cannot enforce them, a concept that is as critical for intellectual property as for any other set of rights. The system must be designed to avoid indifference to intellectual property rights, as well as to deter outright theft.

Nevertheless, exempting the original patent holder from the definition of patent assertion entities could have significant limitations. The fact that the one asserting the patent also filed for the patent, or spent resources trying to commercialize it, is no guarantee that the patent is valuable or that it is being launched at an appropriate target. The infamous and controversial inventor Jerome Lemelson illustrates the problem. According to press reports, the Lemelson Foundation and its barcode related patents received close to $\$ 1.5$ billion in settlements over a 14 -year period in the 1990s and early $2000 \mathrm{~s} .{ }^{48}$ These patents were invalidated by the courts in 2005.

In light of the issues described above, we should be wary of creating definitional boundaries that will have the effect of suggesting that original patent holders should be exempted from measures to curb monetization abuses, and we certainly should be wary of measurements that exclude original patent holders from the categories to be examined. Thus, I have chosen to include both those who file for patents and assert them as well as those who purchase patents and assert them in the definition for this study.

In short, in choosing the terms and definitions for this article, I have opted for simple and broad terms, avoiding the fine distinctions that are increasingly appearing in the discourse. For example, rather than nonpracticing entities or patent assertion entities, I use the term monetizers. It has the advantage of not distinguishing among actors based on the form they choose, and of referencing individuals as well as "entities." I define monetizers as those whose core business involves licensing and litigating patents, rather than making products. This definition has the virtue of simplicity, and allows one to speak broadly about the phenomenon. I must

${ }^{48}$ See Roger Parloff, Taking on the Trolls, ForTUne (Mar. 17, 2014). 


\section{PATENT DEMANDS \& STARTUP COMPANIES}

reiterate, however, that the topic is complicated, and that in a politically charged atmosphere, every word is at issue.

One also must decide what activity to measure, in addition to choosing the definition of those involved in the activity. As described above, prior work has explored monetization in the context of activity after the patent holder files a lawsuit. There are excellent practical reasons for focusing on lawsuits. Activity before that time generally is shrouded in nondisclosure agreements and difficult to access through public documents. This study, however, was intended to look at the effects of a range of patent activity. Thus, in framing the questions in the survey, I chose the term "patent demands" and defined the term broadly to include demand letters, threats of litigation, or lawsuits. Specifically, respondents were asked whether they had "received patent demands, for example, demand letters, threats of litigation, or infringement lawsuits."

\section{Brief History and Overview of Startup Financing}

Although today's technology startups have created the enduring image of the scrappy, underfinanced underdog that goes on to create the next Facebook from someone's garage, technology startups used to require massive investments to get off the ground. ${ }^{49}$ Early venture capital-backed technology companies required sizable investments in manufacturing, engineering, personnel, and professional services in order to enter the market. $^{50}$ As a result, early tech companies like Digital Equipment Corporation (DEC) and Tandem had to get their funding from large venture capital firms such as Arthur Rock and Kleiner Perkins. ${ }^{51}$

Thanks to the success of these prototypical venture-backed initiatives, the operating model established by these early venture capitalists has endured to this day. ${ }^{52}$ Under this model, venture capital firms "provid[e] capital to high-potential businesses in exchange for partial ownership of the firm." $" 53$ Traditionally, venture capital funding has filled the crucial gap between early seed funding, such as money from friends and family, and later rounds of investment. ${ }^{54}$ As protection for risking large

\footnotetext{
${ }^{49}$ Ben Horowitz, How Angel Investing Is Different Than Venture Capital, BusINESS INSIDER (Mar. 2, 2010), http://www.businessinsider.com/how-angel-investing-is-differentthan-venture-capital-2010-3.

${ }^{50} I d$.

${ }^{51} I d$.

${ }^{52} I d$.

${ }^{53}$ Brian L. Dos Santos, Pankaj C. Patel, \& Rodney R. D’Souza, Venture Capital Funding for Information Technology Businesses, 12 J. ASS'N INFO. SYSTEMS 57, 59 (2011).

${ }^{54}$ Bob Zider, How Venture Capital Works, HARV. BuS. REV., Nov.-Dec. 1998, at 131, 132.
} 
amounts of capital on nascent businesses, venture capitalists take an active role in managing them, with the expectation that enough of these companies will become successful to provide sufficient returns on their investments. ${ }^{55}$ By insisting on direct involvement in the operation of a company, commonly in the form of seats on the company's board, venture capitalists seek to leverage their significant experience in the relevant industry to provide new entrepreneurs with seasoned advice. ${ }^{56}$ Venture capitalists also insist on certain downside protections that allow them to protect their investments in the company if circumstances change. ${ }^{57}$ For example, venture capitalists will usually require that their interest in a company be issued as preferred equity that comes with a liquidation preference, which allows the venture capitalists to get their money out first if the company is liquidated. $^{58}$ Another common requirement for a venture-backed deal is anti-dilution protection, which allows the venture capital firm to maintain its percentage of equity ownership in the event of a subsequent round of financing by requiring that the venture capital firm gets issued additional shares to preserve its current equity position at the expense of common stockholders. ${ }^{59}$ Though these requirements can entail significant sacrifices on the part of founders, the risky nature of investments in their companies often leaves little choice.

The importance of venture capitalists' willingness to invest in highrisk companies must not be understated. In particular, this willingness provides an essential lifeline to entrepreneurs, whose businesses usually cannot access lower-cost capital early on due to their minimal assets. ${ }^{60}$ "Uncertainty is inherent in startup companies because their innovative products and business plans are untested at the time of investment." Given how difficult it is for a new startup to achieve early success in its chosen market, if venture capitalists were not tolerant of failure, many promising startups would otherwise be liquidated after early progress proved unsatisfactory. ${ }^{62}$ This risk tolerance does far more than prevent a venture capitalist's early exit. Research shows that those venture capitalists that are more tolerant of failure tend to pick more innovative startups to

\footnotetext{
${ }_{56}^{55} \mathrm{Id}$. at 133.

${ }^{56} I d$. at $138-39$.

${ }_{57}^{57} \mathrm{Id}$. at 134.

${ }^{58} I d$.

${ }^{59} \mathrm{Id}$.

${ }^{60} \mathrm{Id}$. at $132-33$.

${ }^{61}$ Abraham J.B. Cable, Fending for Themselves: Why Securities Regulations Should Encourage Angel Groups, 13 U. PA. J. Bus. L. 107, 121 (2011).

${ }^{62}$ Xuan Tian \& Tracy Yue Wang, Tolerance for Failure and Corporate Innovation, REV. OF Fin. STUD. 211 (2014).
} 


\section{PATENT DEMANDS \& STARTUP COMPANIES}

invest in. ${ }^{63}$ In turn, startups supported by such venture capitalists have more successful initial public offerings and produce greater numbers of patentspatents that tend to have a greater impact on their respective markets. ${ }^{64}$ In general, venture-backed businesses have a significantly higher rate of survival than those without venture backing. "65 It is unsurprising, then, that in the years since their rise to prominence, venture capital firms have become "important intermediaries in financial markets, providing capital to new ventures that might otherwise have difficulty attracting financing.,"

Although venture capital firms remain an important part of startup financing, a lot has changed since the early days of the tech industry, and the needs of newly-formed startups are now quite different. Modern startups are far less capital-intensive than they used to be, and now frequently require less money than the typical minimum venture capital investment. ${ }^{67}$ As a result, there is often what some have called a "funding gap" between the amount covered by seed funding, which is usually below $\$ 500,000$, "and the minimum amounts venture capital funds invest . . . [which is] typically $\$ 5,000,000 . " 68$ In addition, venture capitalists may ask for more control than a modern startup can afford in its earliest stages. In addition, venture capitalists have a lengthy diligence process and can take up to six months to decide whether they will invest, which may be far too slow for a startup in dire need of funds. ${ }^{69}$ Finally, and quite significantly, venture capitalists may leverage their equity ownership and board seats to force a founder out of the company if the venture capitalist determines that the founder is responsible for poor performance, an aspect that founders would, understandably, wish to avoid. ${ }^{70}$

As a result, funding sources outside the traditional venture-backed system have risen in prominence to meet the changing needs of founders. One such source is the angel investor, a wealthy individual that funds promising startups before they are ready for venture capital. ${ }^{71}$ Unlike

${ }^{63} I d$. at 211 .

${ }^{64} \mathrm{Id}$.

${ }^{65}$ A. L. Zacharakis \& G. D. Meyer, Lack of Insight: Do Venture Capitalists Really Understand Their Own Decision Process?, 13 J. Bus. Venturing 57, 57-76 (1998).

${ }^{66}$ Dos Santos et al., supra note 53. at 58.

${ }^{67}$ Cable, supra note 61, at 108; see also Horowitz, supra note 49.

${ }^{68}$ Cable, supra note 61 , at 108 .

${ }^{69}$ Martin Zwilling, Top 10 Sources Of Funding For Start-ups, ForBES (Feb. 12, 2010), http://www.forbes.com/2010/02/12/funding-for-startups-entrepreneurs-financezwilling.html; see also Horowitz, supra note 49.

${ }^{70}$ See generally Zider, supra note 54, at 136 (noting that VC equity ownership and deal structure give VCs the ability to make management changes for companies with mediocre performances).

${ }^{71}$ Cable, supra note 61, at 108-09. 
venture capitalists, angel investors usually do not insist on control rights like board seats, leaving founders with the ability to control their company's direction and strategy for longer. ${ }^{72}$ Angels are also willing to invest smaller amounts of money, which helps fill the "funding gap" and allows founders to raise money from a greater number of sources. ${ }^{73}$ Combined with the fact that angels often use their connections to bring other angels on board, companies can sometimes get by on an initial financing consisting solely of angel investments. ${ }^{74}$ Nevertheless, companies backed solely by venture capitalists do better overall than those with backing from a combination of venture capitalists and angels or angels alone, in terms of achieving an initial pubic offering or a merger. Research has shown, however, that companies with angel-only financings were significantly less likely to fail than companies receiving venture financing. ${ }^{75}$

An even more recent development is the rise of startup incubators, which provide not only financial resources but also strategic planning assistance and infrastructure like office space and computer equipment, in exchange for equity. ${ }^{76}$ Participants benefit both from this expert guidance, and also from the ability to network internally with other companies being supported by the same incubator. ${ }^{77}$ Furthermore, a fledgling startup can stick with an incubator from inception straight through its initial public offering, should it come to pass. In fact, since many incubators focus on early stage companies, they often sell their interests once the company goes public, thus focusing more on short-term profit than long-term influence over the company. ${ }^{78}$

Although the process by which potential investors engage with startups can vary greatly depending on the parties involved, one increasingly common factor considered by many investors - particularly in the technology industry - is the strength of a company's intellectual property position. ${ }^{79}$ In today's highly competitive landscape - in which investors are presented with numerous possible ventures with each seeking support for a new, unproven technology-a company's intellectual property

\footnotetext{
${ }^{72} I d$. at 129.

${ }^{73}$ See Horowitz, supra note 49.

${ }^{74}$ Cable, supra note 61, at 131.

${ }^{75}$ Cable, supra note 61, at 129.

${ }^{76}$ Meredith M. Brown, Michael P. Harrell, \& William D. Regner, Internet Incubators: How to Invest in the New Economy Without Becoming an Investment Company, 56 BuS. LAW. 273, 273 (2000).

${ }^{77}$ Id. at $273-74$.

${ }^{78} \mathrm{Id}$. at 274.

${ }^{79}$ Joseph Hadzima, Bruce Bockmann, \& Alexander Butler, IP in early stage commercial and investment success, Intellectual Asset MgMt., Mar.-Apr. 2010, 49.
} 


\section{PATENT DEMANDS \& STARTUP COMPANIES}

situation can make a large difference in determining which companies ultimately get funded. Research has shown that there is a "marked correlation between success" as measured by a company achieving its initial public offering or getting acquired "and a company having developed (or possessed) intellectual property," a correlation that is "even greater ... [when] companies . . . have good or strong intellectual property positions." $" 80$ As one venture capitalist has commented, "[it is] impossible to get financing without a good patent strategy, freedom to operate and good prospects of patentability." 81

Given the importance of venture backing to the startup community, as well as the advantage of a concentrated body of respondents, this study examines the viewpoints and experiences of venture capitalists and their portfolio companies in relation to patent demands. Details of the study are provided in the design and methodology section below.

\section{E. Design of Study and Participants}

The study was conducted in September and October of 2013. Two surveys were prepared, one for venture capitalists and one for companies within the portfolios of those venture capitalists. Both surveys were submitted to the Western Institutional Review Board, which determined that the research met the exemption criteria for human subjects research under 45 C.F.R. $\S 46.101(\mathrm{~b})(2) .{ }^{82}$ The surveys were prepared for distribution through the National Venture Capital Association. The survey language was tested by staff members of the National Venture Capital Association, as well as by selected board members of the Association who volunteered to serve as testers.

The National Venture Capital Association distributed both versions of the survey by email to their member venture capitalists, asking that the members fill out the venture capital survey themselves and distribute the company survey to their portfolio companies. Participants were told that the responses would be anonymous and reported only in the aggregate. The results were anonymized prior to delivery to the author.

Prior to the survey, the National Venture Capital Association had not taken a position on patent assertion. In introducing the survey, member companies were told the following:

\footnotetext{
${ }^{80}$ Id. at 49.

${ }^{81}$ See Chien, Patent Assertion and Startup Innovation, supra note 12.

${ }^{82}$ See Letter from Western Institutional Review Board dated September 4, 2013 (on file with author).
} 
In light of recent patent reform discussions on Capitol Hill, the NVCA is working with Robin Feldman, Professor and Director of the Institute for Innovation Law at University of California Hastings to gather information about the current environment for patent assertions within the venture-backed company community. While we have anecdotal information that patent trolling has become increasingly problematic for many of our members and their portfolio companies, particularly in the IT space, we do not have data to quantify the size and breadth of the issue.

The survey included questions about the respondent's individual experiences followed by questions about the respondent's overall impressions. In order to ensure that answers about the respondent's individual experiences were derived from direct experience to the extent possible, venture capital respondents were asked to answer the direct experience questions only for companies "upon whose boards you personally sit as an investor."

Early in the survey, participants were asked whether they or one of their companies had ever received patent demands. Those who answered, "no" were routed directly to the final set of questions related to the respondent's perceptions of patent demands.

\section{F. Study Limitations}

Research through voluntary responses always contains significant limitations. The results can be skewed by those who choose to respond, presenting less than a full picture of the experiences of all members of the group. Similarly, the framing of the question can create a demand problem, priming those who have experienced the problem to respond. Most important, the answers represent the respondent's perceptions and cannot be individually verified. For example, if a respondent notes that the company has spent $\$ 50,000$ responding to patent assertions, there are no public documents or other independent data to verify the figure.

Individual perceptions, however, may be useful for some of the inquiries in this type of survey. For example, to the extent we are examining whether the issue of patent demands occupies an entrepreneur's mindshare, thereby potentially causing distraction, the entrepreneur's own impression of whether a problem exists can be helpful.

Along the same lines, if legislators and regulators believe they are responding to the needs of a particular sector of the market, it is useful to know whether that sector of the market agrees. For example, to the extent governmental officials believe patent assertion is necessary to attract 


\section{PATENT DEMANDS \& STARTUP COMPANIES}

venture capital for startups, it is important to know whether the venture capitalists have the same perception. Nevertheless, perceptions are no guarantee of reality for issues such as how widespread a problem may be or the ways in which it is manifesting itself.

I note in particular that the results may be skewed by the large percentage of respondents who operate in the information technology sector. This could reflect a particular interest of those in the information technology sector in the issue of patent demands, which could, in turn, suggest that patent demands are a particular problem in that sector, an issue that will be addressed further below. It could also simply suggest that a larger portion of venture-backed companies are in the information technology industry. Nevertheless, it is important to note the prevalence of responses from that sector.

Looking at both venture capitalists and their portfolio companies not only provided a broader sample, it also allowed a comparison of whether the companies themselves agreed with their venture backers about the extent of the problems, the costs involved, etc. In other words, it provided some small measure of confirmation.

Research of any kind into patent demand activity is quite difficult. Although one can study patent demands that proceed to a full-blown lawsuit, evidence suggests that these are only the tip of the iceberg. For patent demand activity outside of the courthouse, information is scarce. Patent interactions are shrouded in nondisclosure agreements. Moreover, for a number of years, companies have been reluctant to speak to reporters or researchers, partly out of fear of retaliation by large players with large patent portfolios. $^{83}$ Thus, an anonymized survey, despite its many limitations, offers a useful vehicle for beginning to understand the issues at hand.

Finally, in noting limitations, it is important to note that a sample size of slightly over 200 respondents is small. The experiences and observations are useful for understanding the venture-backed company community, and the information is important, in light of the research obstacles described above. Nevertheless, any observations should be tempered with the caution appropriate for a grouping of this limited size.

\footnotetext{
${ }^{83}$ See, e.g. Ewing \& Feldman, supra note 35, at 4. "[W]e called people who had licensing arrangements with [a patent aggregator], we called people who were defendants in lawsuits involving [the aggregator's] patents, we called every single company being sued by [a monetizing shell company]. No one would talk to us."); see also Alex Blumberg \& Laura Sydell, This American Life: When Patents Attack, National Public Radio (July 22, 2011), transcript available at http://www.npr.org/blogs/money/2011/07/25/138576167/when-patents-attack.
} 


\section{G. General Characteristics of Respondents}

Respondents were given a choice of choosing information technology, life sciences, clean energy or other as the sector in which they operate. Venture capitalists were permitted to mark all categories that apply, which resulted in a total percentage that exceeds $100 \%$.

Of the venture capitalists that responded, $68 \%$ have portfolio companies operating in the information technology sector. ${ }^{84} 41 \%$ of the venture capitalists have companies operating in the life sciences sector and $19 \%$ in the clean energy sector. $10 \%$ of the venture capitalists have companies operating in sectors other than those categories, and respondents described those sectors as consumer apparel, oil and gas, retail, new media, industrial technology, and growth equity. ${ }^{85}$

In which sectors do your portfolio companies operate?*

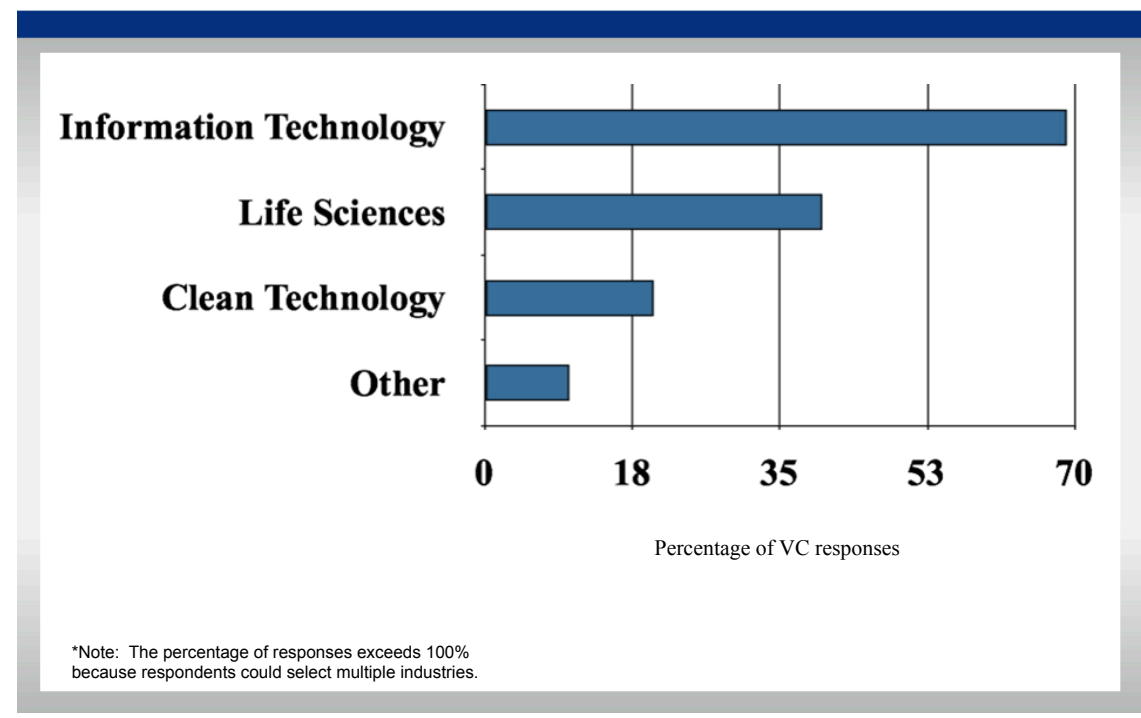

The portfolio companies that chose to respond were even more strongly concentrated in the information technology sector, with $81 \%$ of respondents indicating that they operate in information technology. $6 \%$ of the companies operate in the life sciences and only $1 \%$ in clean energy. $12 \%$ of the portfolio companies indicated that they operate in other sectors, which they further described as internet technology, consumer electronics,

\footnotetext{
${ }^{84}$ According to NVCA staff, the dominance of the information technology sector among respondents is also reflected in the overall membership.
} 


\section{PATENT DEMANDS \& StARTUP COMPANiES}

consumer technology, eCommerce, eCommerce retail, retail, 3D printing, health information technology, Finance, consumer apparel, and education.

In which sector does your company operate?

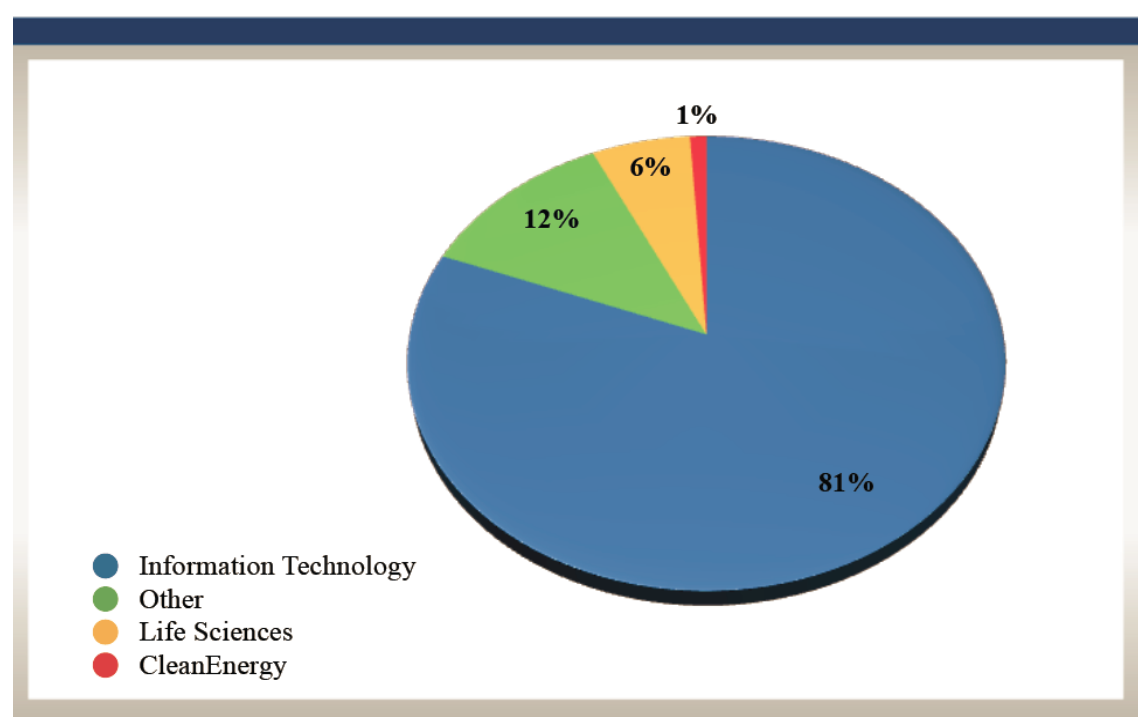

Portfolio companies were also asked where their company is located, and the results mirror common perceptions of startup hubs. The largest group (32\%) was located in California, with most of that in Northern California. Other groupings were located in Illinois (13\%), Massachusetts (11\%), New York (7\%), Colorado (7\%), Texas (7\%), Wisconsin (4\%), Virginia (2\%), and Washington (2\%). The Appendix contains a list of respondent locations by state. 
Location of startup company headquarters

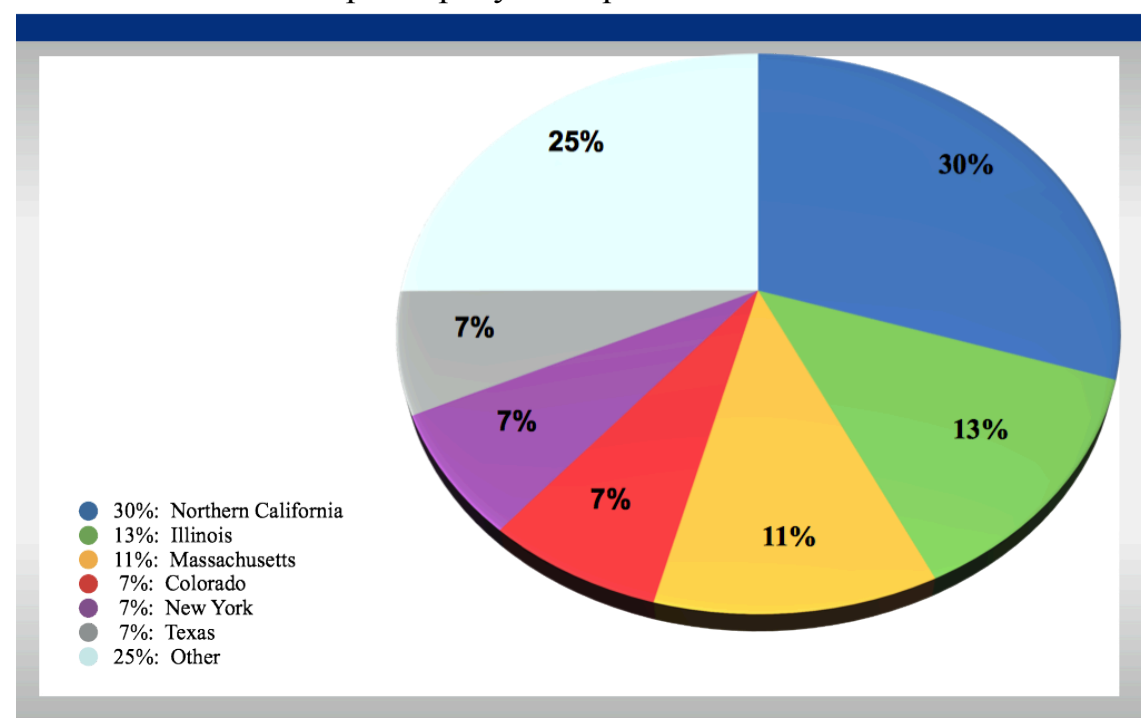

\section{RESUlTS}

The article will separate the results into the following sections. The first section looks at the extent of patent demands against venture-backed companies, based on the direct experiences of the venture capitalists and their portfolio companies. This section also considers whether patent demands are a technology sector problem only. The second section examines the source of patent demands against venture-backed companies and the timing of those demands. The third section examines the impact of patent demands, looking at both the economic impact and the personal toll on the individuals involved. The fourth section examines the respondents' perceptions of whether patent assertion is helpful or harmful for the venture-backed community and how patent demands affect a venture capitalist's decision whether to fund a company.

\section{A. The Extent of Patent Demands Against Venture-Backed Companies}

Survey responses suggest an extensive amount of patent demand activity against venture-backed companies. Specifically, the survey asked venture capitalists whether any of their portfolio companies have received patent demands. Patent demands were defined broadly, with the question listing licensing demand letters, threats of litigation, and infringement lawsuits as examples of patent demands.

$70 \%$ of the venture capitalists reported that they have portfolio companies that have received patent demands. 
Percentage of venture capitalists whose portfolio companies have received patent demands*

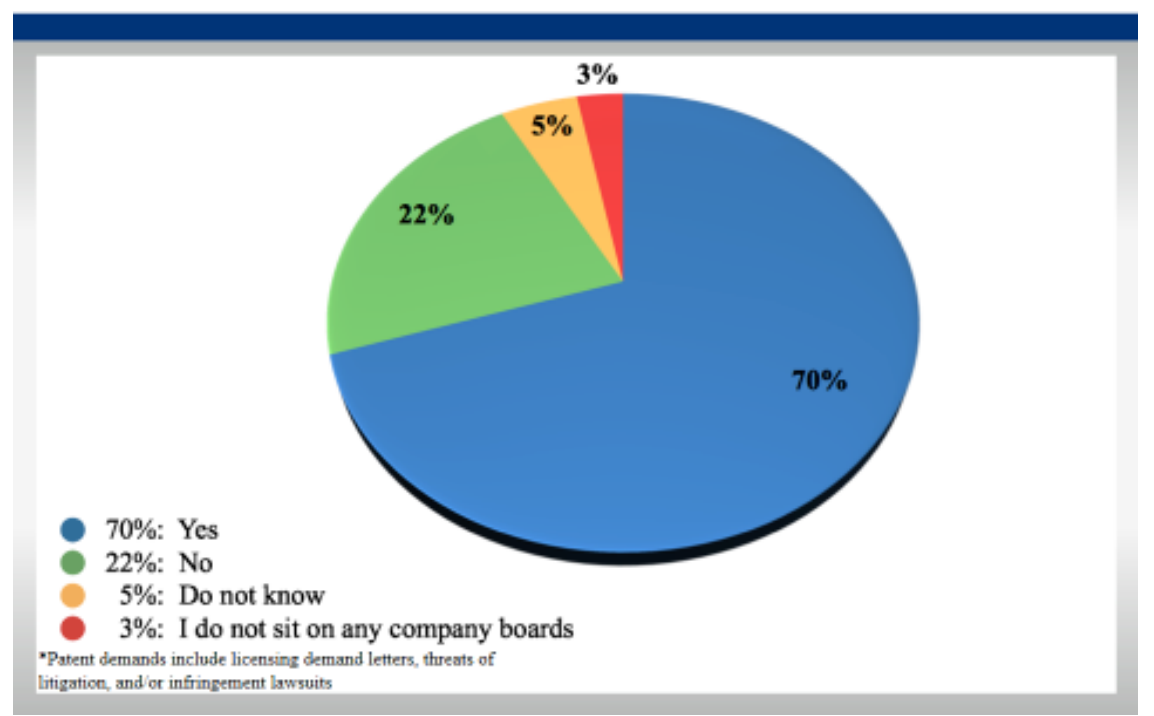

In addition, the venture capitalists were in general agreement that patent demands are increasing against venture-backed companies. 79\% responded that the number of patent demands have increased over the last five years for their portfolio companies overall.

Change in the level of demands received by venture capitalists over the last 5 years

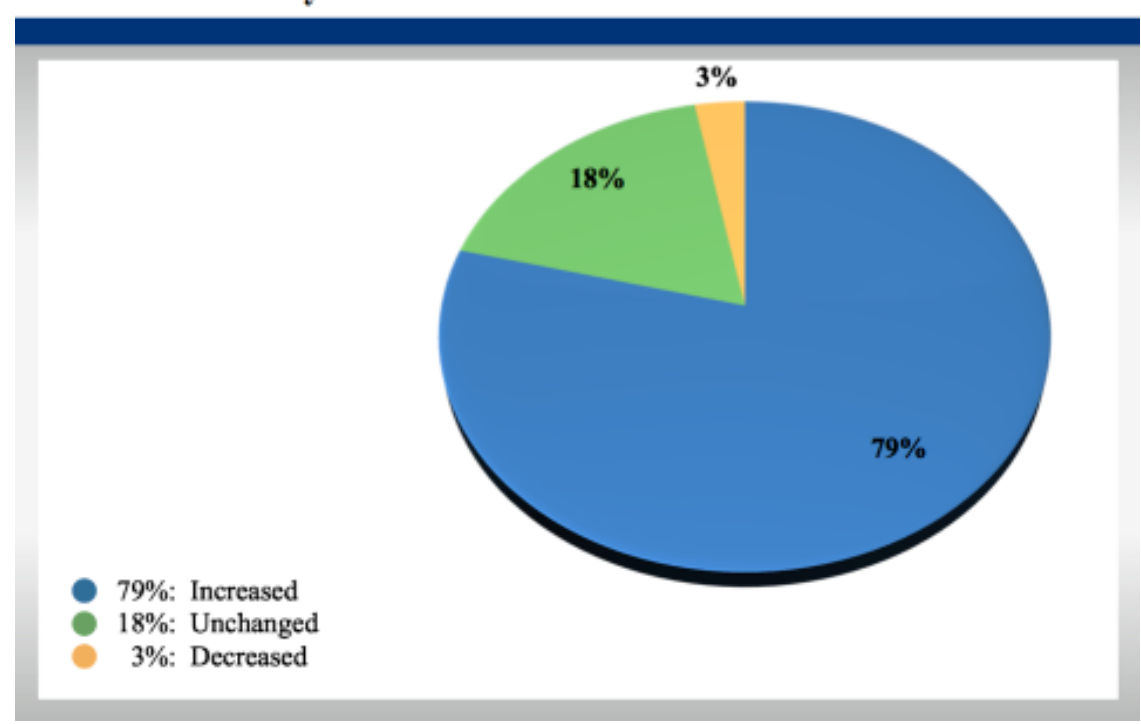


The data suggest, however, that the phenomenon is best understood on an industry wide basis, in other words, looking at the venture-backed industry as a whole. Not all portfolio companies have received patent demands. For example, with venture capitalists whose companies have received patent demands, $60 \%$ have seen demands asserted against up to one-quarter of their portfolio companies, and 35\% have seen demands asserted against between one-quarter and half of their portfolio companies. Similarly, with the portfolio companies themselves, $31 \%$ have received patent demands. Even the $31 \%$ number, however, is striking. It suggests that roughly one in three venture-backed companies must figure out how to respond to a patent demand.

On the whole, patent demands continue to dominate in the information technology sector. Venture Capitalists whose companies had received patent demands were asked whether they had experienced those demands in the information technology sector, life sciences, clean energy or other. Again, to account for broad venture portfolios, venture capitalists were permitted to mark all categories that applied, with the result that the total will exceed $100 \%$.

Of the venture capitalists whose companies have received patent demands, $70 \%$ have experienced those demands in the information technology sector. Patent demands, however, are not limited to the information technology sector. $30 \%$ of the relevant venture capitalists had received patent demands in the life sciences sector. In addition, 10\% have received patent demands in the clean energy sector, and $5 \%$ in other sectors.

Sectors in which venture capitalists have experienced patent demands

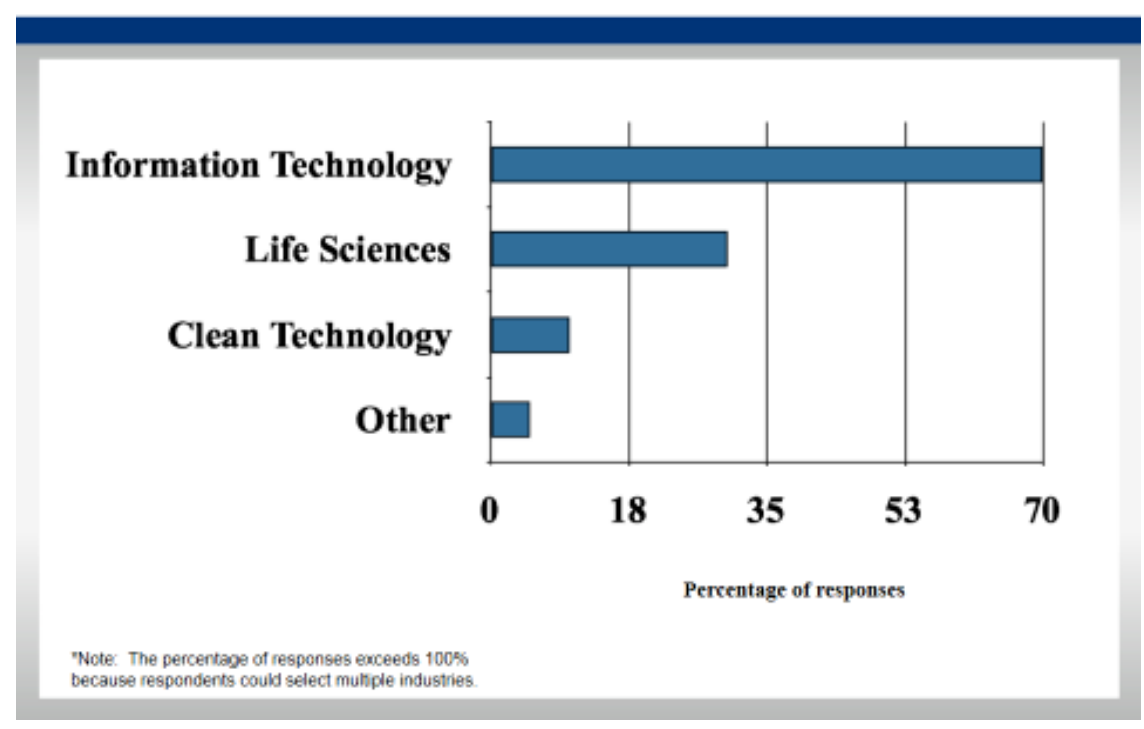




\section{PATENT DEMANDS \& STARTUP COMPANIES}

\section{B. Source and Timing of Demands}

The study asked both the venture capitalists and the portfolio companies if they could identify the type of entities initiating the patent demands against them. As described in the methodology section above, respondents were asked whether the patent demands came from entities whose core activity is licensing and/or litigating patents as opposed to those whose core activity is not licensing and/or litigating patents.

For $59 \%$ of the venture capitalists, the patent demands came either all or mostly from those whose core activity is licensing or litigating patents. For another $21 \%$ of the venture capitalists, the demands came from an equal mixture of those whose core activity is licensing and litigating patents and those whose core activity is not. The question allowed respondents to answer separately for "all" or "most", although the chart below groups those responses.

Source of patent demands experienced by venture capitalists

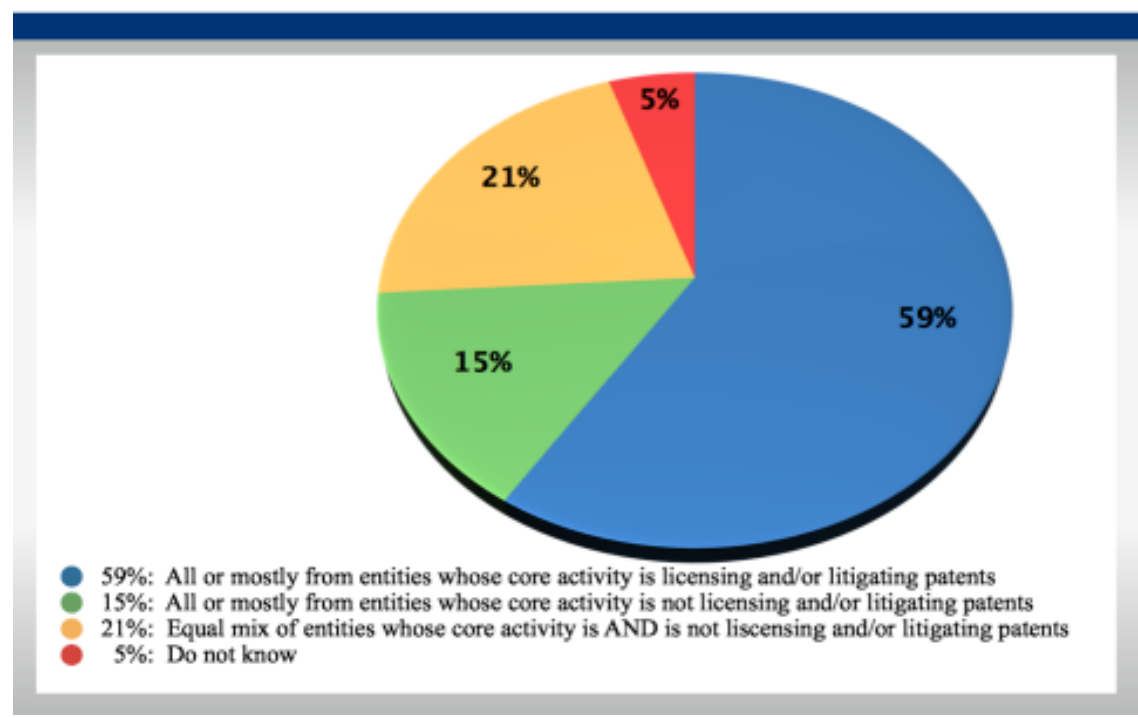

The portfolio companies responded with similar percentages on this question. For $66 \%$ of the portfolio companies, the patent demands came either all or mostly from those whose core activity is licensing or litigating patents. For another $11 \%$ of the portfolio companies, the demands came from an equal mixture of those whose core activity is licensing and litigating patents and those whose core activity is not. These results suggest that monetizers are initiating most of the patent demand activity against startups. 
Source of patent demands experienced by companies

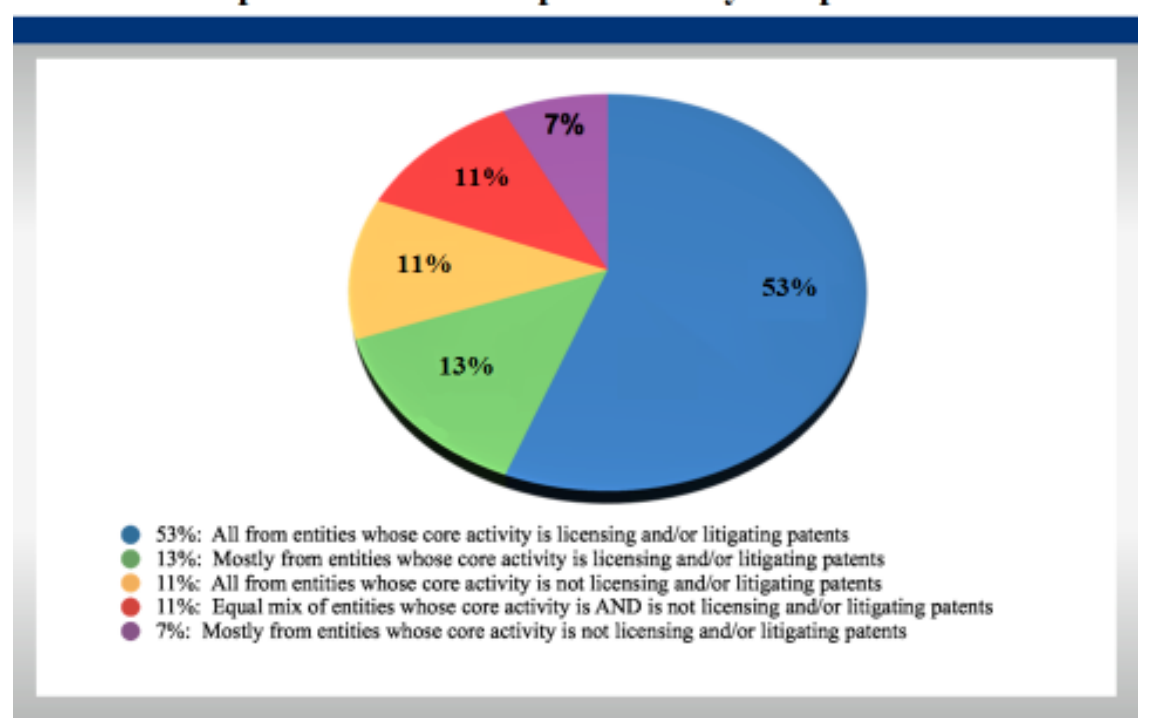

The study also looked for evidence of whether patent demands were timed to correspond with funding infusions. Anecdotes have circulated in the venture-backed community of companies receiving demands immediately after receiving their first round of funding. The results, however, did not reveal evidence of widespread patent demands related to receiving initial funding. Only $11 \%$ of portfolio companies reported receiving patent demands within one year of receiving their first round of venture funding, and 53\% reported that they received their first patent demand more than a year after receiving the first round of venture funding. Moreover, $27 \%$ of the portfolio companies received their first patent demand before receiving any funding at all. Thus, we could find no systematic evidence of demands timed to coincide with initial rounds of venture funding. In contrast, in Chien's interviews with venture capitalists, some noted that demands "seemed to be dictated by an event in the company's development_publicity/success, an M\&A or funding event, or the company's IPO.",86

Examining the initial round of venture funding cannot completely answer the question of whether there are patterns of demands timed to coincide with funding events. It is possible that monetization involves a variety of approaches, with some monetizers targeting funding events. It is also possible that monetizers target funding events on the whole, and no pattern would emerge from looking only at initial funding. Nevertheless, we

\footnotetext{
${ }^{86}$ See Chien, Startups and Patent Trolls, supra note 10, at 11. An initial public offering
} ("IPO") is the first sale of stock by a private company to the public. 


\section{PATENT DEMANDS \& STARTUP COMPANIES}

did not find evidence of a sustained pattern of patent demands against venture-backed startups following their initial round of funding.

\section{Significance and Cost of Impact of Patent Demands on Venture-Backed Startups}

The study also examined the impact of patent demands on venturebacked startups, both from a quantitative and a qualitative perspective. Venture capitalists were asked whether patent demands had a significant impact on any of their portfolio companies. Examples of significant impacts listed in the question included distracting management, expending resources, or altering business plans.

Only $8 \%$ of the venture capitalists reported that the patent demands had no impact on any of their portfolio companies that received them. In contrast, $74 \%$ of the venture capitalists reported that patent demands had either a highly significant or a moderately significant impact on the companies that received them, including distracting management, expending resources, or altering business plans. Another $18 \%$ of the venture capitalists reported that patent demands had a mild impact.

Have patent demands had a significant impact on any of your portfolio companies, for example, distracting management, expending resources or altering business plans? (venture capitalists)

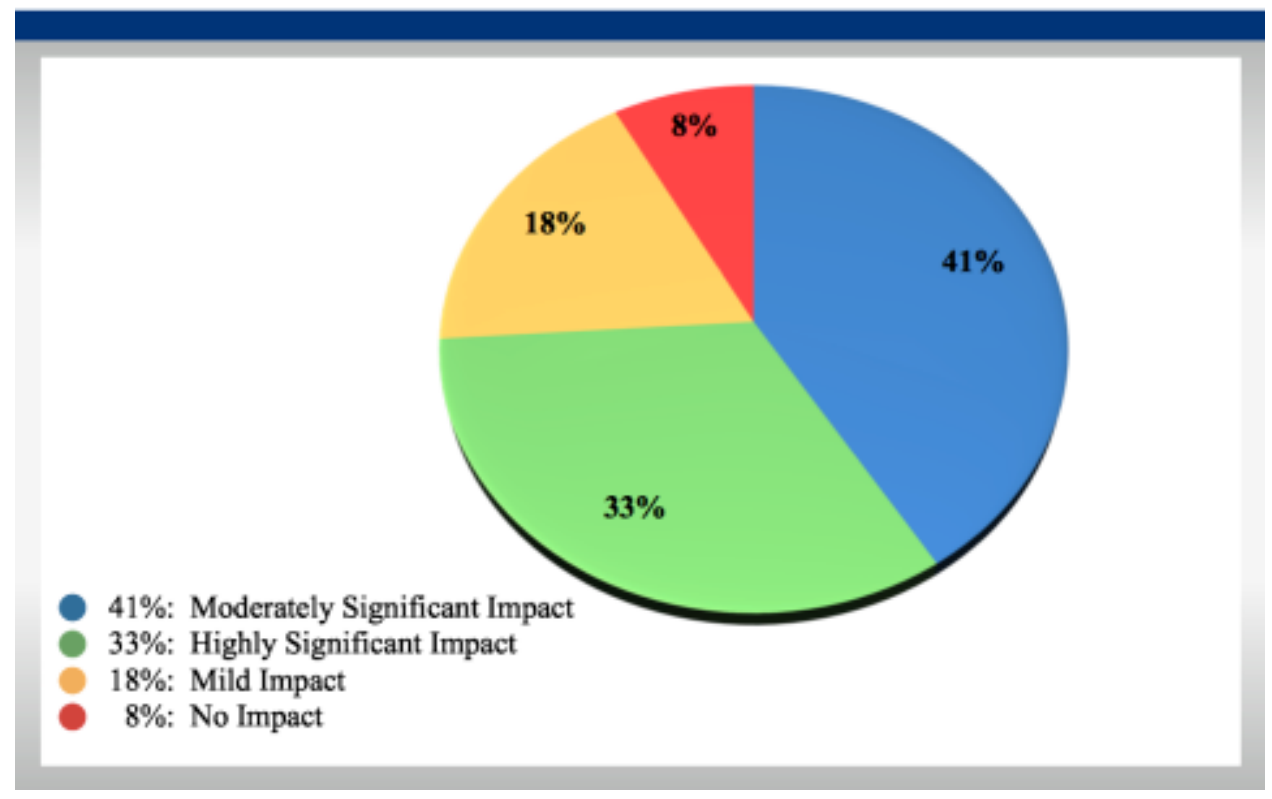

With the portfolio companies, 58\% reported that patent demands had either a highly significant or moderately significant impact on their company, including distracting management, expending resources or 
altering business plans. Another 31\% reported that patent demands had a mild impact. Similar to the venture capitalists, only $9 \%$ of the portfolio companies reported that patent demands had no impact at all.

Have patent demands had a significant impact on your company, for example, distracting management, expending resources or altering business plans?

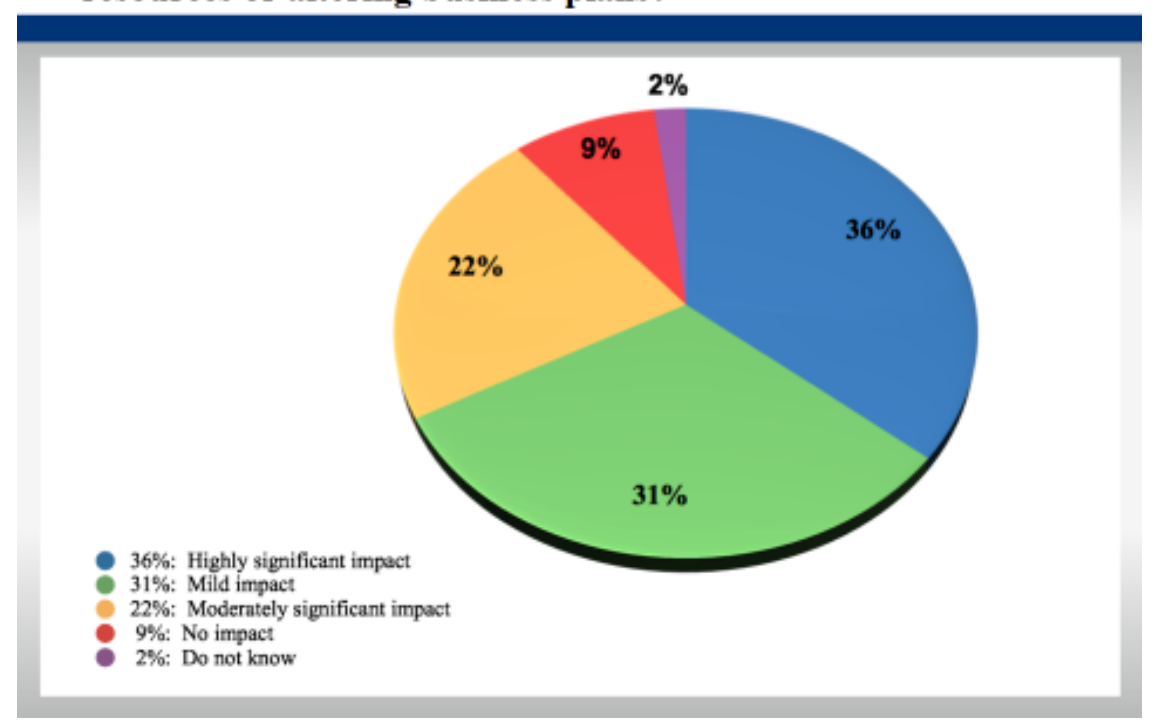

It is interesting to note the difference between responses from the venture capitalists and responses from the companies regarding the extent of the impact on patent demands. Although roughly $90 \%$ of both groups identified some impact, the venture capitalists rated that impact as highly or moderately significant far more frequently (74\%) than did the companies themselves (58\%). Although it is impossible to know without further examination, one could hypothesize various possible explanations for the difference. First, it is possible that the companies are in a better position to evaluate the true nature of the impact, given their more intimate involvement with day-to-day operations. Alternatively, the venture capitalists might be in a better position, given their breadth of their experience spread out across many companies. The difference could also reflect the small sample size. It may be that the venture capitalists who responded had sufficient experience to have encountered greater impact demand examples, while the companies that choose to respond did not happen to include ones that had experienced the greater impacts. Finally, it is also possible that the perception reflects the general "macho" culture of startup entrepreneurs. In other words, entrepreneurs may be prone to saying, "no problem, we can handle anything thrown at us," while venture capitalists may be inclined to temper that interpretation. 


\section{PATENT DEMANDS \& STARTUP COMPANIES}

Professor Colleen Chien's study also looked at the impact of patent demands on startups. Using a more drastic definition of impact, Chien found that $40 \%$ of startups in her study that had received a patent demand from a patent assertion entity reported a "significant operational impact." 87 Professor Chien defined significant operational impact as "a business strategy pivot, product change, business/business line exit, delay in hiring or meeting operational milestone, and/or a reduction in the value of the company." $" 88$ Although the questions differ in both the type of impact studied and the issue of the source of the relevant patent demands measured, both studies demonstrate the impact that patents demands are having on startup companies.

In terms of the cost of dealing with patent demands, the present survey asked both venture capitalists and portfolio companies to estimate the average cost to prepare for and defend against patent demands. For the venture capitalists, the survey asked for an average cost per company. The questions noted that such costs could include time for company officers and employees, costs of outside counsel and consultants, or other costs.

$57 \%$ of the venture capitalists estimated that the average cost per company to prepare for and defend against patent demands exceeds $\$ 100,000$. Another $21 \%$ estimated that the cost of preparing for and defending against patent demands totaled between $\$ 50,000$ and $\$ 100,000$.

Average cost per company to prepare for or defend against patent demands as experienced by (venture capitalists)

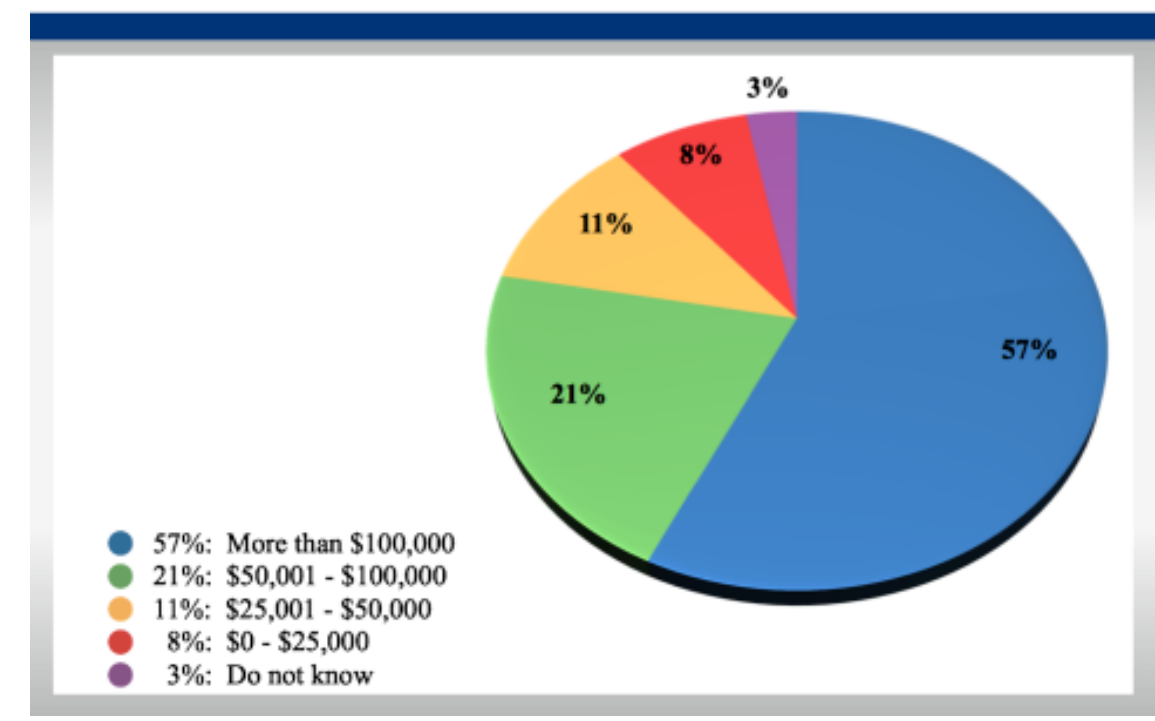

\footnotetext{
${ }^{87}$ See Chien, Startups and Patent Trolls, supra note 10.

${ }^{88}$ See id.
} 
Portfolio companies estimated the costs of preparing for and defending against patent demands at a lower number. Only $40 \%$ of the portfolio companies estimated that costs of patent demands exceeded $\$ 100,000$, in comparison to $57 \%$ of the venture capitalists. In addition, $29 \%$ of the portfolio companies estimated the costs at below $\$ 25,000$, in contrast to $8 \%$ of the venture capitalists who estimated the cost at below $\$ 25,000$. The two groups were roughly in agreement with each other for the percentage of companies that spent between $\$ 50,000$ and $\$ 100,000$, as well as for the percentage of companies that spent between $\$ 25,000$ and $\$ 50,000$. In short, a higher percentage of the venture capitalists reported average costs within the highest category than did the companies. One could hypothesize explanations along the same lines as those discussed in the prior question. In particular, the venture capitalists who responded may have had sufficient experience to encounter higher cost patent demand examples, while the companies that choose to respond did not happen to include ones that had experienced the higher costs.

Approximate cost per company to prepare for or defend against patent demands as determined by startup companies.

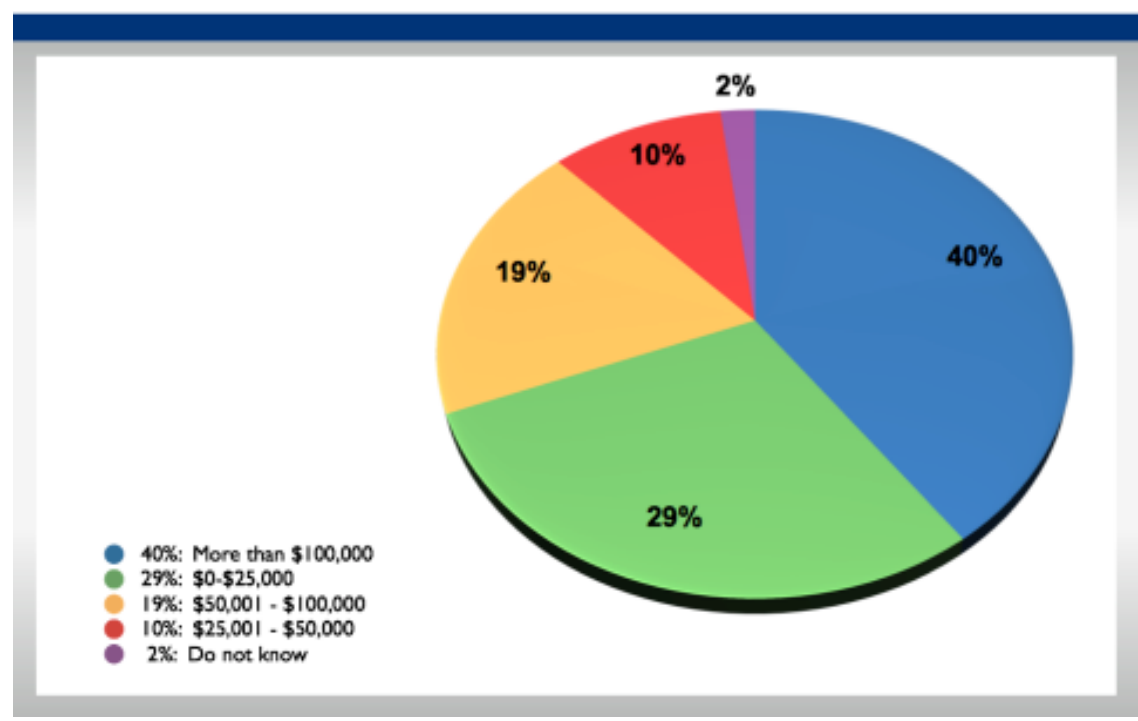

Professor Chien's survey suggests a higher average cost figure for defending against patent demands. Again, her study was based on the costs of defending against patent demands specifically by patent assertion 


\section{PATENT DEMANDS \& STARTUP COMPANIES}

entities - similar to what this study describes as monetizers. ${ }^{89}$ Depending on whether the startup chose to settle or fight, the average costs reported in Chien's survey and interviews ranged from $\$ 168,000$ to $\$ 857,000 .^{90}$ These higher figures may reflect the ability of patent assertion entities to impose higher costs on their targets. ${ }^{91}$

Finally, the question for the present survey may have been framed insufficiently to capture the significantly higher cost examples that were captured in Professor Chien's survey. In particular, the highest cost category in the present survey was defined as over $\$ 100,000$, while in the comments, some respondents noted that their costs had run into the millions.

\section{The Human Factor: Respondents Elaborate on the Impact of Patent Demands}

The most striking results in the study flowed from the venture capitalists and portfolio companies who took the time to provide details of the impact of patent demands on their companies. The survey provided space for respondents to elaborate on the impact of patent demands, and elaborate they did.

\section{Extraordinary Impacts}

Some companies and venture capitalists described extraordinary effects of patent demands on a particular company. One company had to raise a bridge round to cover costs related to dealing with patent demands. Another company spent millions of dollars defending against a lawsuit from "patent trolls," and the company went under due to lack of funding. One venture capitalist described an "M\&A [merger and acquisition] transaction escrow held up and millions spent in defense of [a] meritless patent suit from a patent troll." Another described a couple of cases in which the companies experienced material financial impacts.

\footnotetext{
${ }^{89}$ For a description of different terms used in the discussion of patent demands, see supra notes 22-43 and accompanying text.

${ }^{90}$ See Chien, Startups and Patent Trolls, supra note 10, at 11.

${ }^{91}$ Patent assertion entities may have large portfolios of patents, some of which include broad claims that are asserted in demand letters sent out by the thousands to small businesses. The accuracy of the infringement claims made in these letters is often difficult to assess without large legal expenditures. Many small businesses may decide to pay licensing fees to these entities to avoid greater costs. See PATENT Assertion AND U.S. INNOVATION, supra note 17.
} 


\section{Distractions to Management and Engineers}

Numerous companies and venture capitalists spoke about the major distractions to management and other employees of the company, including time spent by engineers. One company noted pointedly that about $40 \%$ of the chief technical officer's time was redirected to fighting two patent infringement lawsuits filed within three weeks of each other. Another company explained that patent demands had absorbed hundreds of hours of the CEO's time and another simply noted that it was a "huge distraction." Many companies described loss of management time to respond to discovery questions and develop a response strategy, and loss of engineering time to make technical workarounds. Over and over again, the companies and the venture capitalists talked about distraction of time and wasted resources.

\section{Cost Impact}

Other companies and venture capitalists underscored the impact of specific costs and the way in which patent demands now add to the general costs of doing business. ${ }^{92}$ For example, one venture capitalist noted that, "[m]ost of portfolio companies now need to hire an in-house general counsel to manage intellectual property matters, including defense against infringement claims. This is becoming a strategically important position to fill."

In asking the companies and venture capitalists to estimate the cost of defending against patent demands, the survey had listed "over $\$ 100,000$ " as the highest number. In the comments section, however, a number of the companies and venture capitalists described costs running into the millions of dollars. In the highest number cited, one startup company explained that it has spent $\$ 4$ million in litigation expenses. A number of others simply referred to costs in the millions of dollars. One company reported that the cost of dealing with patent demands is the company's second biggest expense after salary, and that it is even larger than the cost of benefits. Others reported diverting money to legal counsel, as well as huge amounts of time spent by management and by the board. As one company noted, "we have had to invest time researching the background of the plaintiffs, the patent, the claim . . . etc. internally to determine how to defend ourselves

\footnotetext{
${ }^{92}$ The present survey did not ask the portfolio companies themselves or the venture capitalists sitting on their boards about the financial scale of the portfolio companies at the time these patent demands were made. Therefore, this study contains no specific analysis of the ratio of patent demand costs to the general costs of doing business.
} 


\section{PATENT DEMANDS \& STARTUP COMPANIES}

from patent demands. . . . We expect to expend more resources as we engage counsel to defend ourselves from the suit. We are still at initial stages for our first lawsuit against an NPE."

\section{The Human Face}

Some companies and venture capitalists described the sheer human toll on those who had to contend with patent assertions.

We received a [cease and desist demand] from a patent troll on Christmas Eve 2011. The experience was new to us, and at the time, it seemed like an existential threat. It ruined my family's Christmas. The troll filed a lawsuit in the spring of 2012. The entire process lasted almost a year and completely distracted our company during the entire event. It took a huge emotional and financial toll on our small company, in addition to slowing down our progress.

One startup company used the following terms to describe the impact on the company: "Abject fear we are being driven out of business so this troll can put a trophy on his wall." In a similar vein, one venture capitalist spoke about the damage to employee morale. Another company commented, "I consider this process to be extortion."

These comments echoed the narratives Professor Colleen Chien has reported in her interviews with a group of small technology companies that had received patent demands from non-practicing entities. ${ }^{93}$ Two of the most poignant comments from Professor Chien's research are the following:

It was agonizing to hand over all the money we had earned from a product we had invented and created ourselves to a firm that invents nothing and creates nothing. Our founder has since lost his house, car [sic] all his assets. ${ }^{94}$

And:

They sued my startup for infringement on a group of insanely broad software patents. While many much larger companies are fighting we do not have the resources to do so. It is the single most frustrating experiences [sic] I've had professionally. Extortion, pure and simple. The troll even

\footnotetext{
${ }^{93}$ See Chien, Startups and Patent Trolls, supra note 10, at 12-14.

${ }^{94}$ Id at 14.
} 
admitted his model was to sue everyone, get settlement dollars because fighting was too expensive. ${ }^{95}$

\section{Other Assorted Impacts}

Other companies and venture capitalists described the difficulties of managing the issue with customers, prospects and funders. One company noted that it had to "sell around the story as new prospects were wary of using the product given the litigation," and a venture capitalist talked about the problem of slowing down sales "as prospective customers assess the risk of claims on the likelihood that the product and support will be available." Another venture capitalist talked about the impact of slowing down next rounds of fundraising. These can be critical issues for a fledgling company, when every funding prospect and every customer matters in trying to gain traction.

A small number of respondents noted more moderate impacts, such as "slightly reorganized business to reflect patent" and "moderate \$ spent externally on legal counsel." One company noted that so far, they have been able to successfully demonstrate they are not party to any of the claims. In addition, one venture capitalist noted that the impact can be "highly variable."

\section{Weak Claims; Wasteful Process}

Many respondents expressed frustration at what they perceive to be the weaknesses of the claims, the wastefulness of the process, and the absurdity of the current process of patent demands as a whole. For example, one company described the following experience:

We spent millions to settle pretty much completely spurious claims. The common approach that these "entities" took was: --make a claim--try to defend it as best they could-eventually offer to settle by observing that it would cost us \$3-5 million to fight it and we might lose, vs. the \$2-3 million they offer to settle initially . . . we'd work to negotiate them down to $\$ 1-2$ million, hold our nose, and pay.

Another noted that the patent asserted against the company was "broad reaching and has been poorly received [in the industry]." Yet another company reported that after spending \$1 million on a case that went

\footnotetext{
${ }^{95} I d$.
} 


\section{PATENT DEMANDS \& STARTUP COMPANIES}

to litigation, the company won but did not recover anything more than court costs, which are typically a small amount. Numerous companies and venture capitalists described the claims as frivolous and no more than nuisance claims.

One venture capitalist took the time to write a side letter with an extensive allegory of "lawn trolls." The lawn trolls arrive in a community and convince all of the neighbors to negotiate over nothing more than the right to enjoy the view of each other's lawns. At the end of the story, the neighborhood has suffered costly and distracting negotiations and incurred significant transaction costs, while "the troll gets rich for its foresight, wisdom, and creation of the market. The moral of the story, according to the venture capitalist, is that lawn trolls do not want fair compensation; what they really want is to tax everyone.

Finally, to paraphrase one venture capitalist who summed up the impact of patent demands on venture-backed companies in a particularly cogent fashion: When companies spend money protecting their intellectual property position, they are not expanding; and when companies spend time thinking about patent demands, they are not inventing. ${ }^{96}$

\section{E. Is Patent Assertion Helpful or Harmful for the Venture- Backed Community?}

A key goal of the study was to test the venture-backed community's own views of whether patent assertion in their field is helpful or harmful. Some have suggested that patent assertion is helpful for startups and venture capitalists because unsuccessful companies can sell their patents to a monetizer if the company fails. In particular, in listing potential positive aspects of patent assertion entities, government officials have suggested that patent assertion entities, "can make it easier for a failed start-up to monetize its patents, providing some insurance for venture capitalists." arguments imply that monetization could spur venture capital investment, providing a benefit for the startup community.

\footnotetext{
${ }^{96}$ The venture capitalist's direct quotation from the study comments is: "More spend [sic] to protect IP position, not necessarily expand. Thinking about trolls asserting not about inventing."

${ }^{97}$ See Ramirez, supra note 20 . In Chien's work, only $5 \%$ of startup companies responded that they have monetized their patents, with some of those explaining that they had either sold the patents along with a product line, sold unused patents, or licensed their patents. See Chien, Startups and Patent Trolls, supra note 10, at 18. Chien points out that many startups do not bother to obtain patents, particularly in the software industry, and notes, in addition, that companies may be embarrassed to acknowledge monetizing patents. Id.
} 
The study tested whether the venture-backed community itself sees patent demands as a positive. The study also examined how patent demands factors into venture capitalists' decisions of whether to invest in a particular startup company. Respondents who had answered at the start of the survey that they had not received patent demands were routed directly to this last set of questions.

Specifically, the survey asked venture capitalists, "how much of a problem are patent demands against venture-backed portfolio companies." Only 6\% responded that patent demands are not much of a problem at all for venture-backed companies. 92\% of the venture capitalists responded that patent demands are a problem for venture-backed companies, with $46 \%$ considering patent demands a widespread problem and 46\% considering patent demands a limited problem.

How much of a problem are patent demands against venture backed portfolio companies? (venture capitalists)

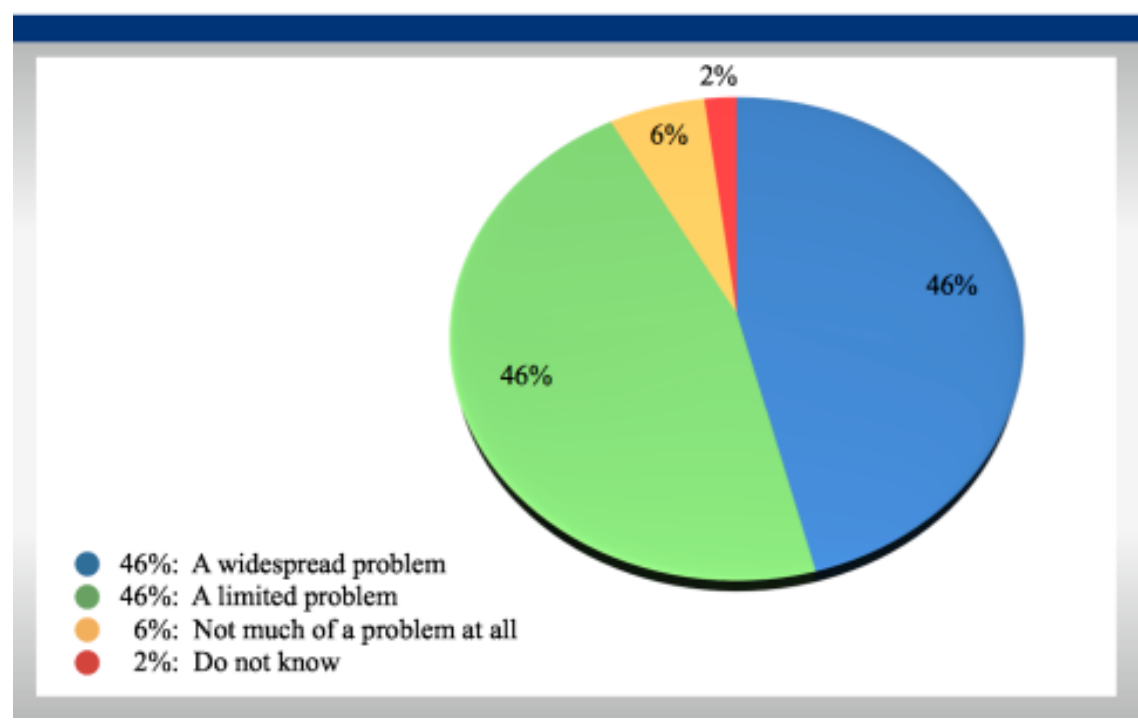

Interestingly, portfolio companies believe even more strongly that patent demands are a widespread problem. Using a variant of the venture capitalist question, portfolio companies were asked, "how much of a problem are patent demands against companies in your industry sector." $64 \%$ of portfolio companies responded that patent demands are a widespread problem in their sector, with another $20 \%$ responding that patent demands are a limited problem. Only $9 \%$ of portfolio companies responded that patent demands are not much of a problem at all. 
How much of a problem are patent demands against companies in your industry sector? (startup companies)

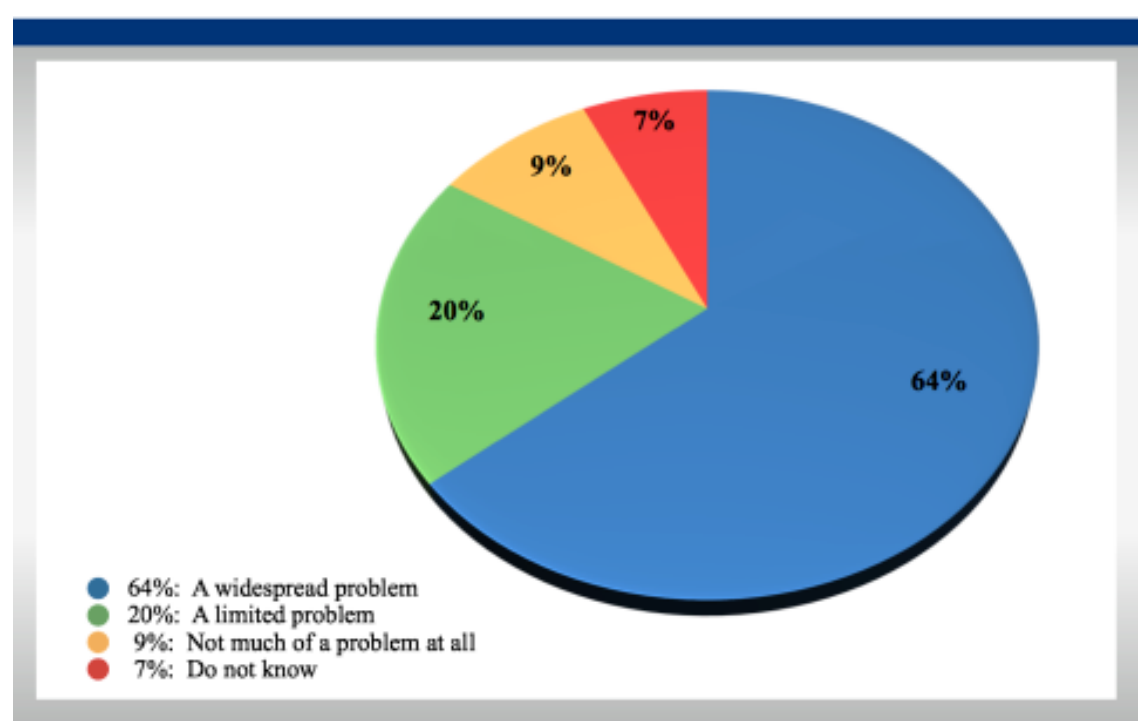

Perhaps one of the most telling set of responses, however, came from asking the venture capitalists how patent demands play into their funding decisions. $65 \%$ of the venture capitalists disagreed with the statement, "[a]s a venture capitalist, in making funding decisions, I consider the potential for selling patents to patent assertion entities if the companies fail." Only 18\% agreed. The largest group of responses came from those who not only disagreed, but disagreed strongly-constituting $41 \%$ of respondents. 
As a venture capitalist, in making funding decisions, I consider the potential for selling the patents to patent assertion entities if the companies fail.

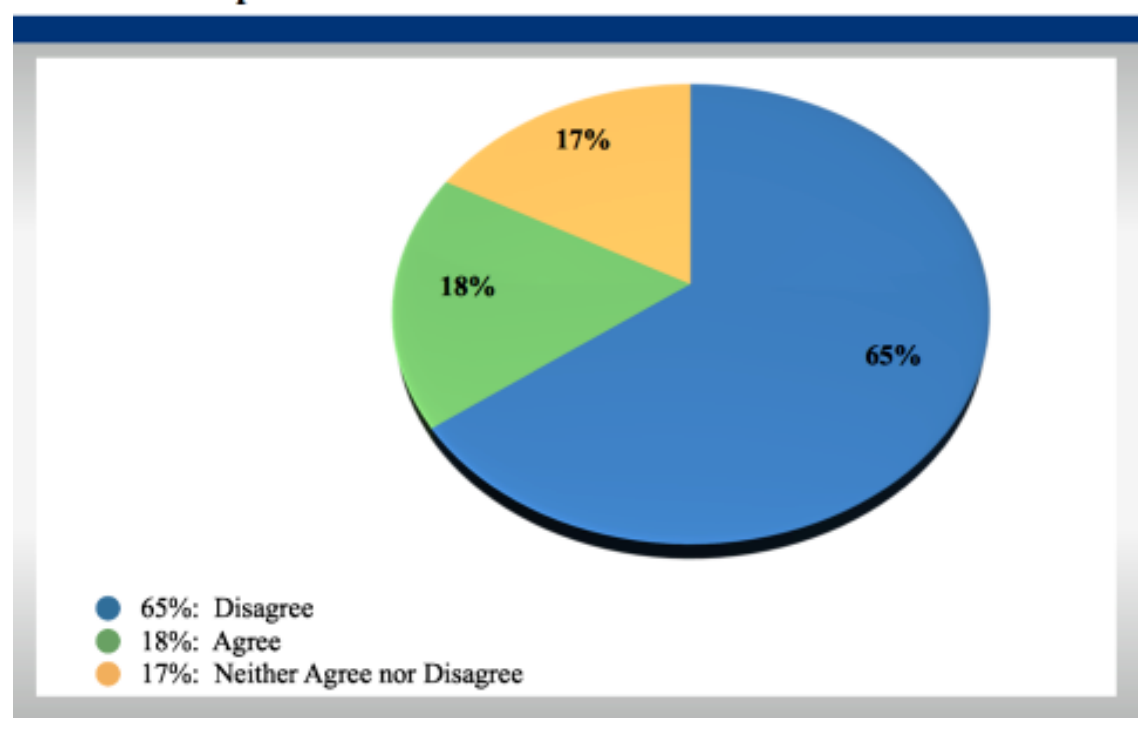

Similarly, when the venture capitalists were asked whether they see "patent assertion as positive for startups and the startup community," $72 \%$ either disagreed or disagreed strongly. Again, the largest group of responses came from those who disagreed strongly-constituting 50\% in this case.

As a venture capitalist, I see patent assertion as positive for startups and the startup community.

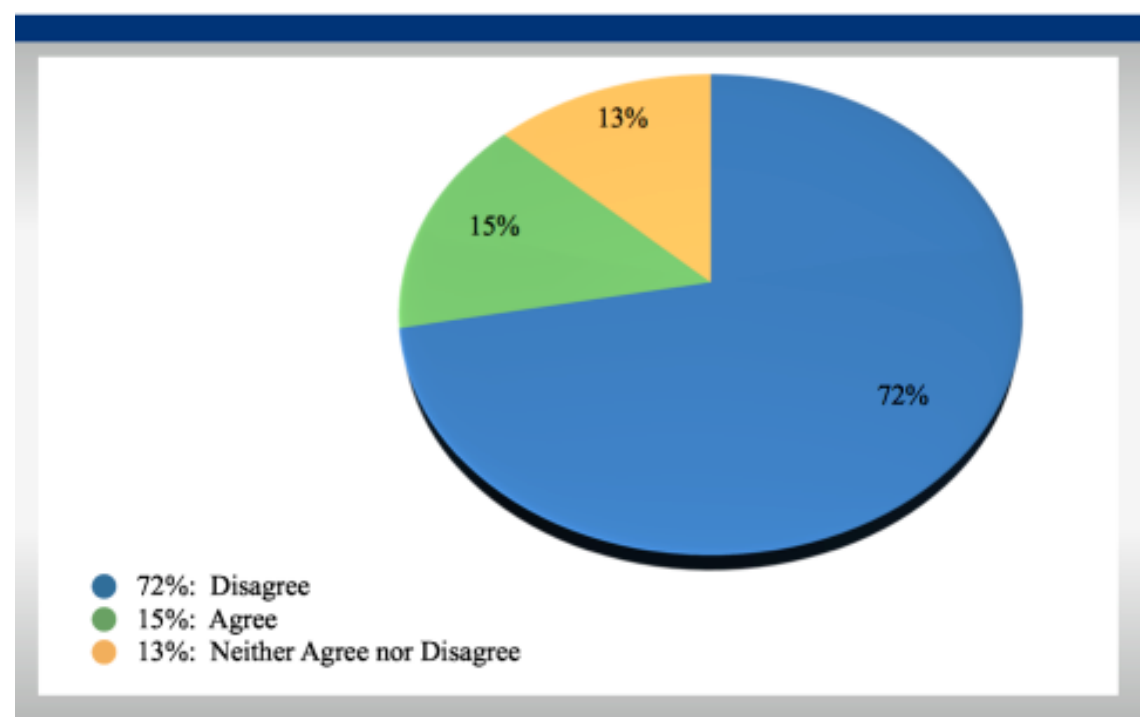




\section{PATENT DEMANDS \& STARTUP COMPANIES}

These results are consistent with comments I heard from venture capitalists as I was designing the survey. As one venture capitalist noted, "VCs swing for the fences; they are not interested in pennies on the dollar."

The results are also consistent with Chien's findings in her interviews of venture capitalists. $78 \%$ of the venture capitalists disagreed that the ability of companies to monetize their patents through "NPEs/'Trolls"" helped innovation; 83\% agreed that NPEs/Trolls are hurting innovation. ${ }^{98}$

The most striking results, however, came in response to the question of whether the venture capitalists would "refrain from investing in a new company that had an existing patent demand." Not a single respondent chose the answer, "no, it is not a factor." Rather, $100 \%$ of venture capitalists indicated that if a company had an existing patent demand against it, it could potentially be a deterrent in deciding whether to invest. Roughly half indicated that it would be a major deterrent on its face, and the other half indicated that they might refrain from investing, depending on the circumstances.

Percentage of venture capitalists who would refrain from investing in a new company that had an existing patent demand

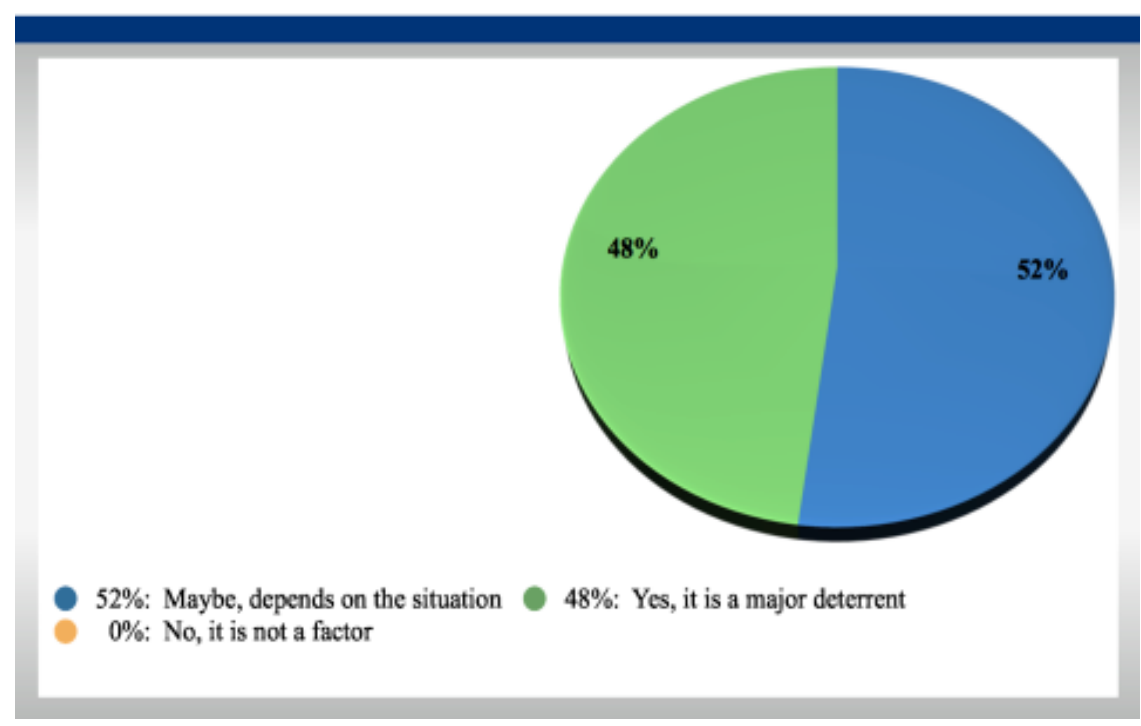

In short, the venture-backed company community overwhelmingly views patent demands as a negative for their industry, does not think about the potential for reselling patents when deciding whether to invest in a

${ }^{98}$ See Chien, Startups and Patent Trolls, supra note 10, at 21. 
company, and would pause before investing in a company that had an existing patent demand against it. Thus, the notion that patent assertion is helpful for the venture capital community is contradicted by the community itself in this study.

\section{CONCLUSION}

The results of surveying 200 venture capitalists and their portfolio companies provide strong indications of the impact that patent demands are having on the venture-backed community. Both the companies and the venture capitalists overwhelming believe that patent demands have a negative impact on the venture-backed community, with all or most of those assertions coming from entities whose core activity involves licensing or litigating patents. These impacts are described in terms of the specific costs expended by the companies and by the distraction to management, engineers, and other employees. Most important, participants described the human toll that patent demands have had on entrepreneurs. In addition, when making funding decisions, the vast majority of venture capitalists do not consider the potential for selling to assertion entities if the company fails. On the flip side, $100 \%$ of venture capitalists indicated that if a company had an existing patent demand against it, it could be a deterrent in deciding whether to invest.

Finally, one venture capitalist provided an excellent summary of the impact of patent demands on venture-backed companies. When companies spend money trying to protect their intellectual property position, they are not expanding; and when companies spend time thinking about patent demands, they are not inventing. 
Patent Demands \& StaRtup Companies

\section{APPENDIX}

Location of Company Headquarters for Portfolio Company Respondents

\begin{tabular}{|c|c|c|}
\hline$\#$ & Answer & $\%$ \\
\hline 1 & Alabama & $1 \%$ \\
\hline 2 & Alaska & $0 \%$ \\
\hline 3 & Arizona & $0 \%$ \\
\hline 4 & Arkansas & $0 \%$ \\
\hline 5 & $\begin{array}{l}\text { California } \\
\text { (No.) }\end{array}$ & $30 \%$ \\
\hline 6 & $\begin{array}{l}\text { California } \\
\text { (So.) }\end{array}$ & $2 \%$ \\
\hline 7 & Colorado & $7 \%$ \\
\hline 8 & Connecticut & $0 \%$ \\
\hline 9 & Delaware & $3 \%$ \\
\hline 10 & $\begin{array}{l}\text { District of } \\
\text { Columbia }\end{array}$ & $0 \%$ \\
\hline 11 & Florida & $0 \%$ \\
\hline 12 & Georgia & $0 \%$ \\
\hline 13 & Hawaii & $1 \%$ \\
\hline 14 & Idaho & $1 \%$ \\
\hline 15 & Illinois & $13 \%$ \\
\hline 16 & Indiana & $0 \%$ \\
\hline 17 & Iowa & $1 \%$ \\
\hline 18 & Kansas & $0 \%$ \\
\hline 19 & Kentucky & $0 \%$ \\
\hline
\end{tabular}


16 YALE J.L. \& TECH. 236 (2014)

\begin{tabular}{|c|c|c|}
\hline 20 & Louisiana & $0 \%$ \\
\hline 21 & Maine & $0 \%$ \\
\hline 22 & Maryland & $3 \%$ \\
\hline 23 & Massachusetts & $11 \%$ \\
\hline 24 & Michigan & $1 \%$ \\
\hline 25 & Minnesota & $1 \%$ \\
\hline 26 & Mississippi & $0 \%$ \\
\hline 27 & Missouri & $0 \%$ \\
\hline 28 & Montana & $0 \%$ \\
\hline 29 & Nebraska & $0 \%$ \\
\hline 30 & Nevada & $0 \%$ \\
\hline 31 & $\begin{array}{l}\text { New } \\
\text { Hampshire }\end{array}$ & $0 \%$ \\
\hline 32 & New Jersey & $1 \%$ \\
\hline 33 & New Mexico & $0 \%$ \\
\hline 34 & New York & $7 \%$ \\
\hline 35 & $\begin{array}{l}\text { North } \\
\text { Carolina }\end{array}$ & $1 \%$ \\
\hline 36 & North Dakota & $0 \%$ \\
\hline 37 & Ohio & $0 \%$ \\
\hline 38 & Oklahoma & $0 \%$ \\
\hline 39 & Oregon & $1 \%$ \\
\hline 40 & Pennsylvania & $\%$ \\
\hline
\end{tabular}


Patent Demands \& StaRtup Companies

\begin{tabular}{|c|c|c|c|}
\hline 41 & Rhode Island & & $0 \%$ \\
\hline 42 & $\begin{array}{l}\text { South } \\
\text { Carolina }\end{array}$ & & $0 \%$ \\
\hline 43 & South Dakota & & $0 \%$ \\
\hline 44 & Tennessee & & $0 \%$ \\
\hline 45 & Texas & & $7 \%$ \\
\hline 46 & Utah & & $0 \%$ \\
\hline 47 & Vermont & & $0 \%$ \\
\hline 48 & Virginia & & $2 \%$ \\
\hline 49 & Washington & & $2 \%$ \\
\hline 50 & West Virginia & & $0 \%$ \\
\hline 51 & Wisconsin & & $4 \%$ \\
\hline 52 & Wyoming & & $0 \%$ \\
\hline & Total & 15 & $100 \%$ \\
\hline
\end{tabular}

